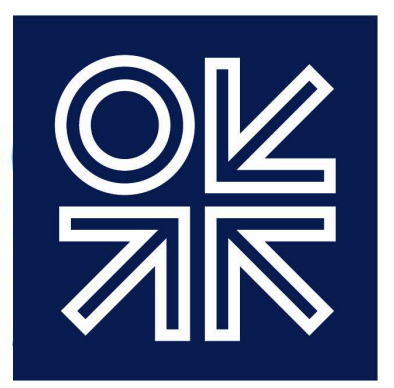

THE OXFORD

INSTITUTE

FOR ENERGY

STUDIES

November 2017

\title{
Assessing Kuwaiti Energy Pricing Reforms
}

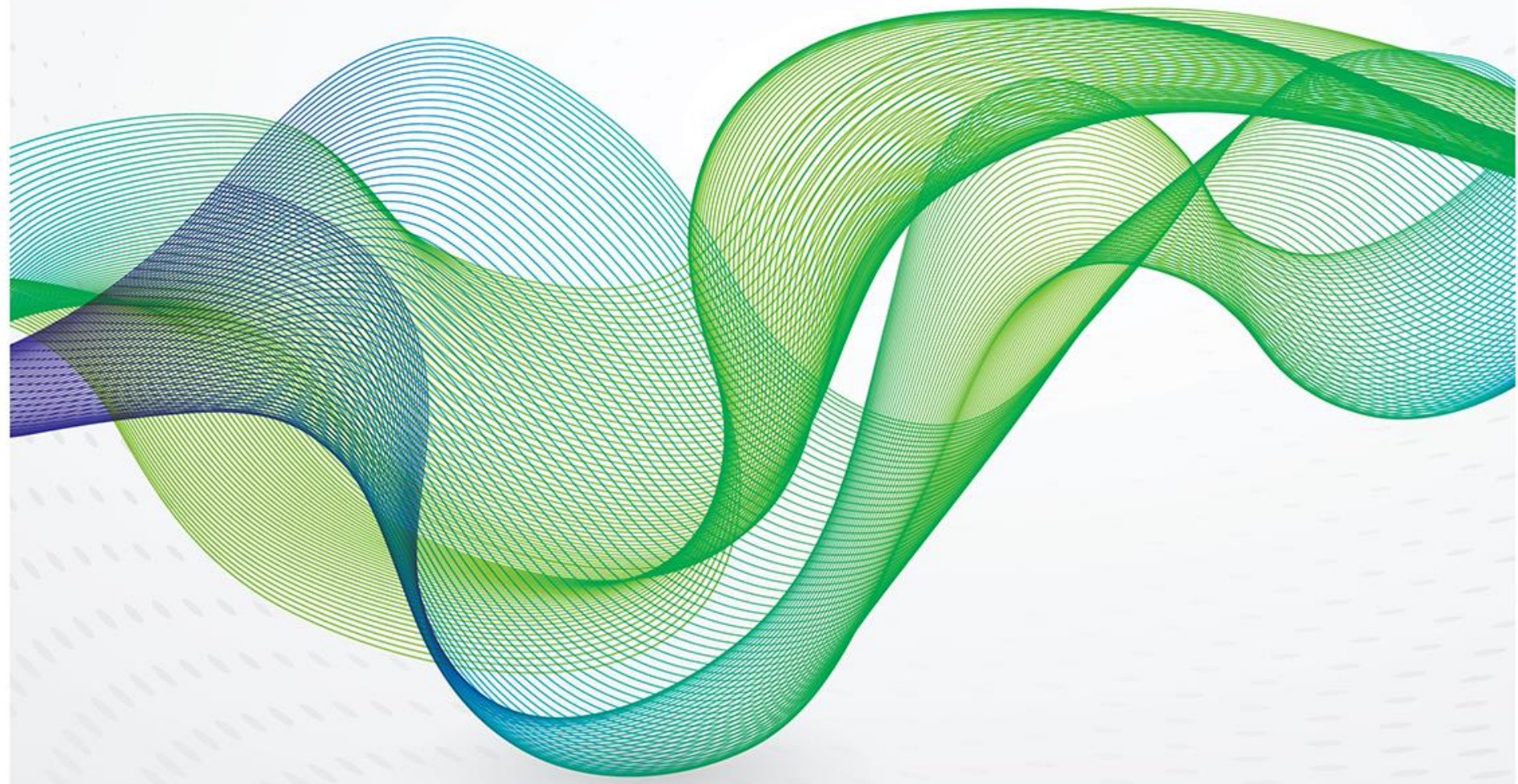



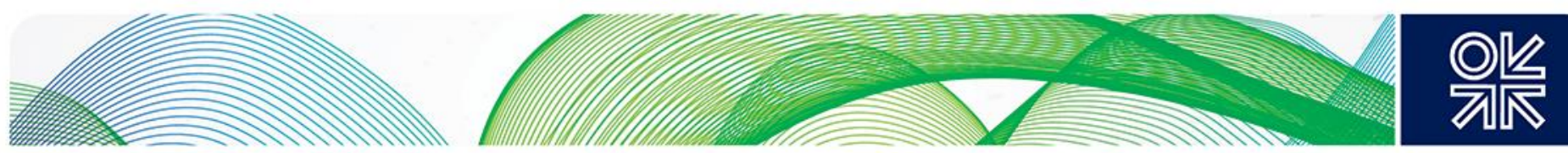

The contents of this paper are the author's sole responsibility. They do not necessarily represent the views of the Oxford Institute for Energy Studies or any of its members.

With thanks to the Kuwait Foundation for the Advancement of Sciences for funding support.

\section{Copyright $\odot 2017$}

\section{Oxford Institute for Energy Studies}

(Registered Charity, No. 286084)

This publication may be reproduced in part for educational or non-profit purposes without special permission from the copyright holder, provided acknowledgment of the source is made. No use of this publication may be made for resale or for any other commercial purpose whatsoever without prior permission in writing from the Oxford Institute for Energy Studies.

ISBN 978-1-78467-093-1

DOI: https://doi.org/10.26889/9781784670931 

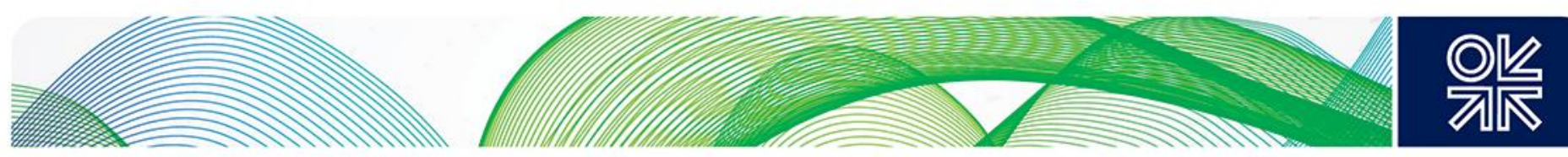

\section{Acknowledgements}

Special thanks to Winthrop Professor Rod Tyers, Dr. Bassam Fattouh, anonymous referees, and to participants of the LSE-OIES Workshop on Energy Pricing Reform in the MENA Region for helpful comments. Thanks are also due for the helpful comments and questions received on earlier versions of this paper at the $5^{\text {th }}$ Asian International Association of Energy Economics Conference and the Cambridge Gulf Research Meeting 2016 at the University of Cambridge. I gratefully acknowledge the hospitality of the Techno-Economics Division at Kuwait Institute for Scientific Research and of Kuwait University during my data gathering and fieldtrip visit as a visiting academic in 2015. My doctoral research is funded by the International Postgraduate Research Scholarship from the Australian government.

Corresponding author: Manal Shehabi, The University of Western Australia, 35 Stirling Highway, Crawley WA 6009 Australia. E-mail: manal.shehabi@research.uwa.edu.au; manal.shehabi@oxfrodenergy.org 

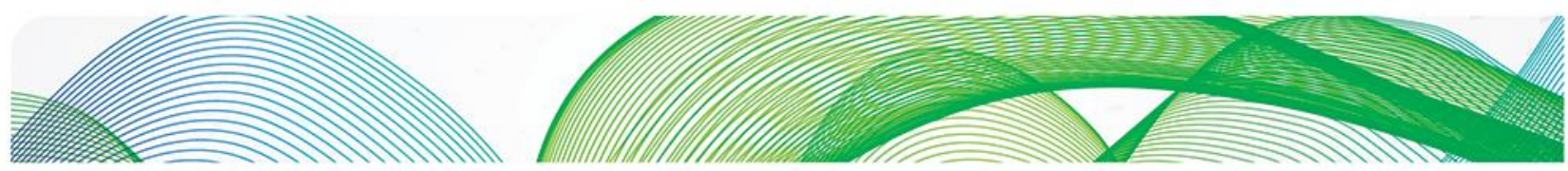

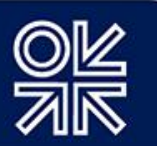

\section{Contents}

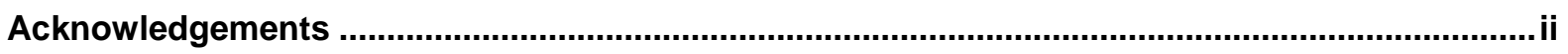

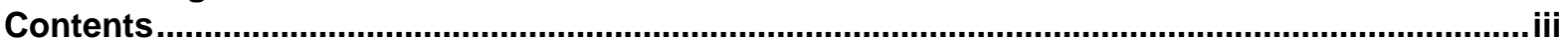

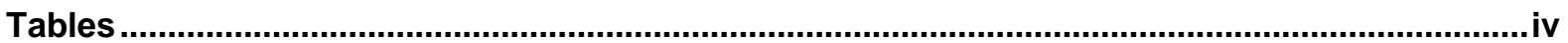

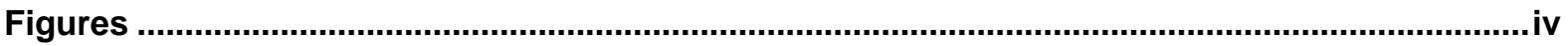

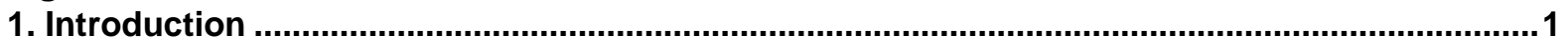

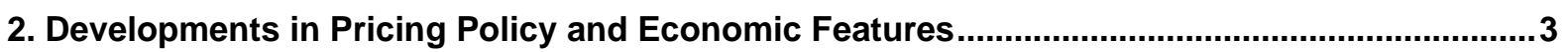

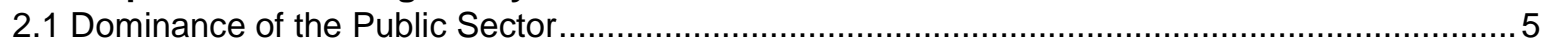

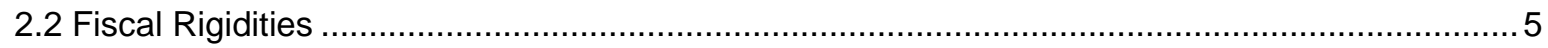

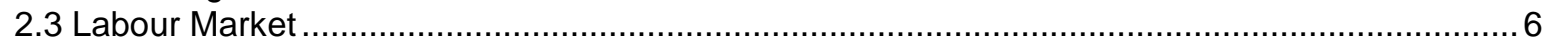

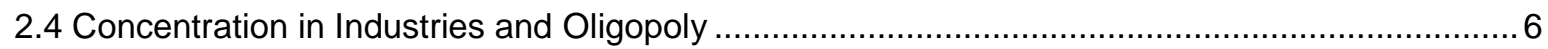

2.5 Kuwait Investment Authority (KIA) ……....................................................................... 7

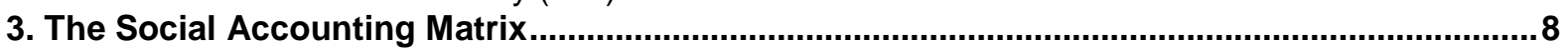

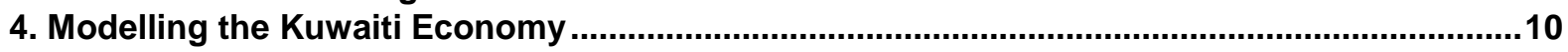

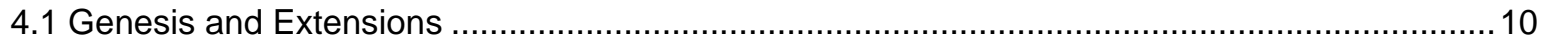

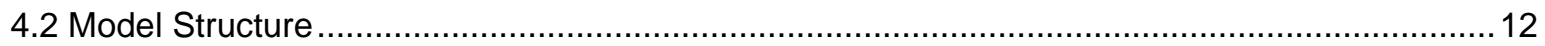

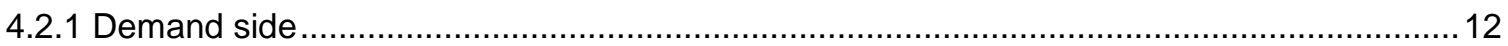

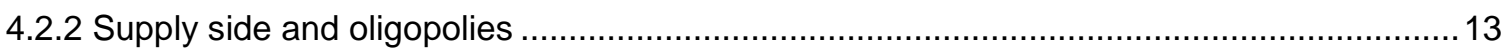

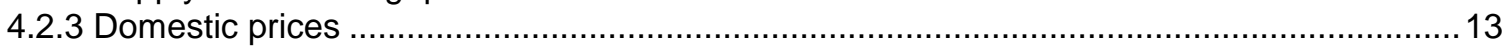

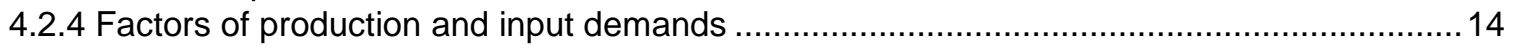

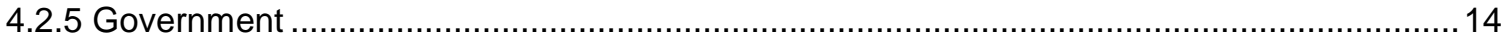

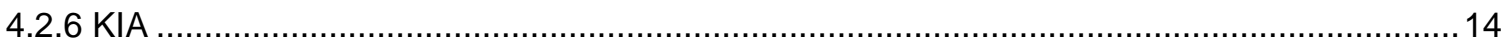

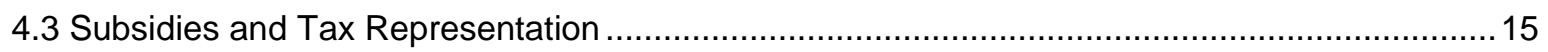

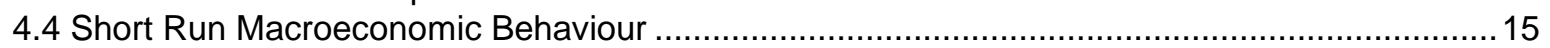

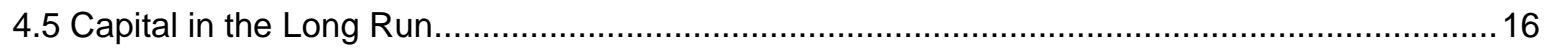

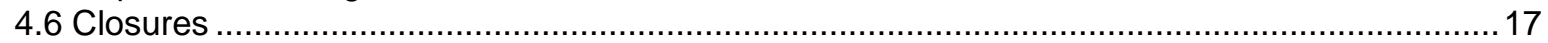

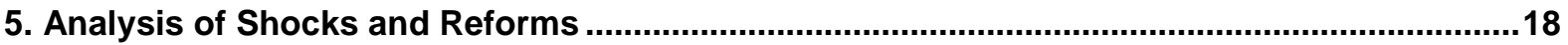

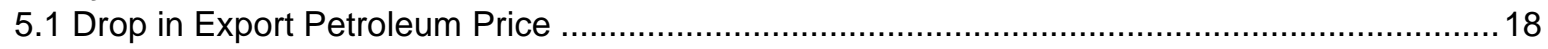

5.2 Oil Price Drop Combined with Subsidy Reform Allowing Adjustments in Fiscal Deficit and

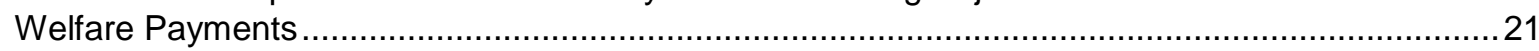

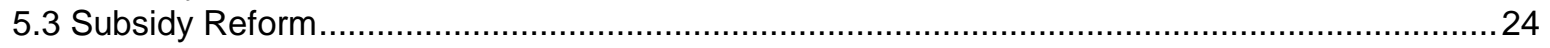

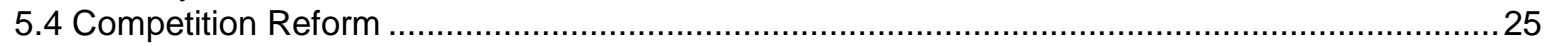

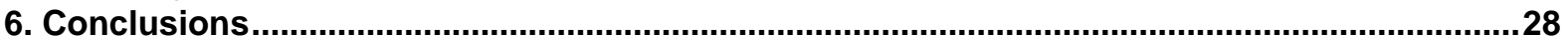

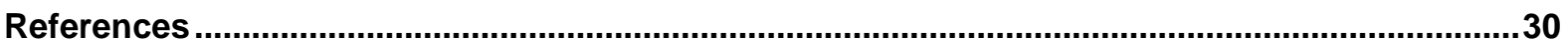

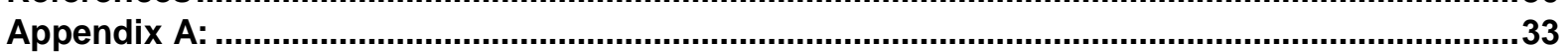

The SAM and its Representation of Broad Economic Structure...............................................33

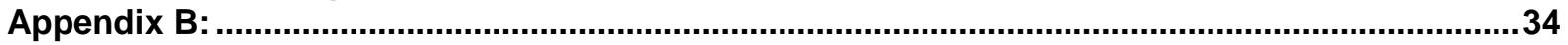

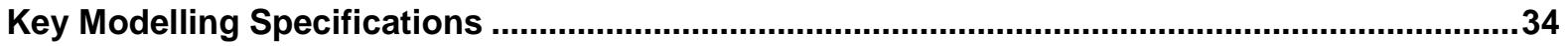

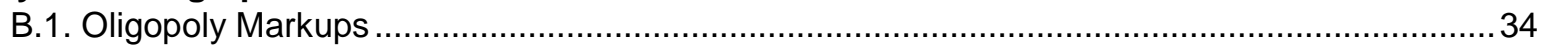

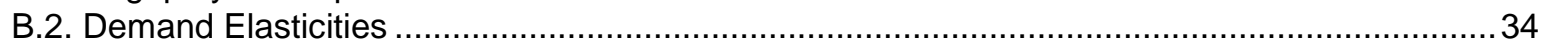

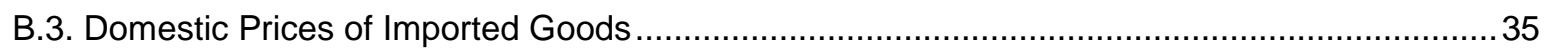

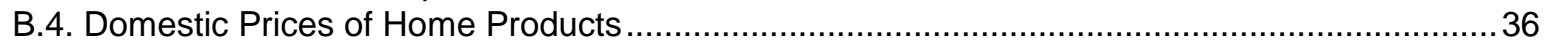

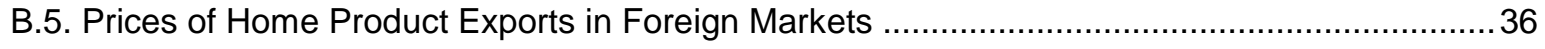

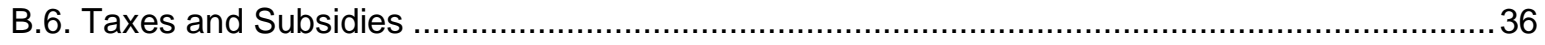

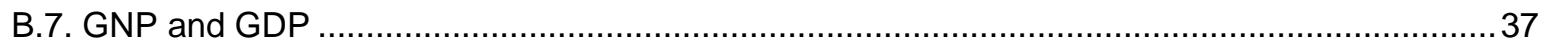

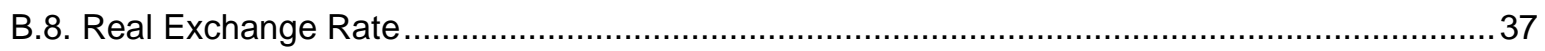



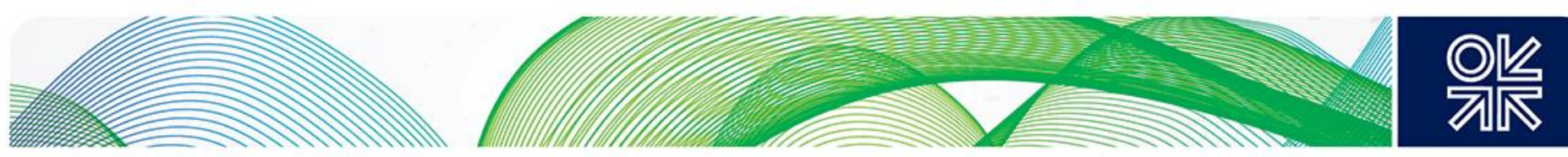

\section{Tables}

Table 1: Breakdown of Kuwait's labor force by nationality and sector, January 2015 ......................6

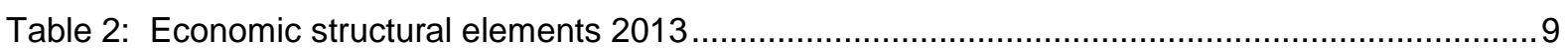

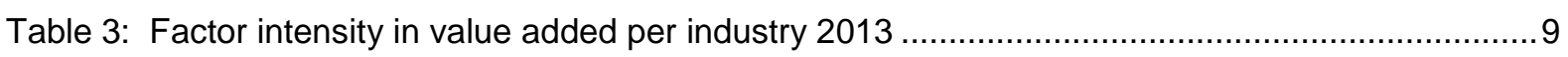

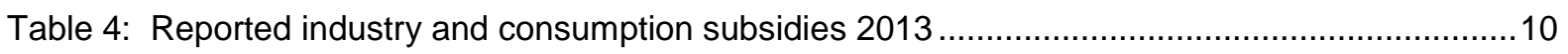

Table 5: Impact of oil export price decline, holding fiscal balance and welfare policies fixed .............19

Table 6: Impact of reform shocks combined with petroleum price declines on selected economic

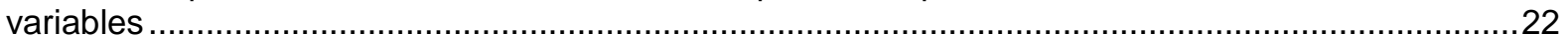

Table 7: Long-run sectoral effects of subsidy and competition reforms following petroleum price

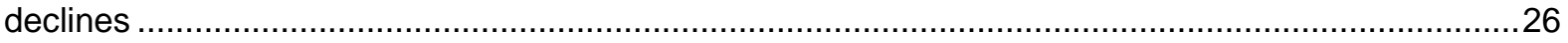

\section{Figures}

Figure 1: Average subsidisation rates for 2014 3

Figure 2: Energy and fuel services subsidies in Kuwait and oil export revenue 2004-2014. ...............4

Figure 3: Cumulative Kuwaiti firm shares of industry revenue........................................................

Figure 4: Comparative tradeoffs and key short-run results of reform scenarios following oil price declines. 

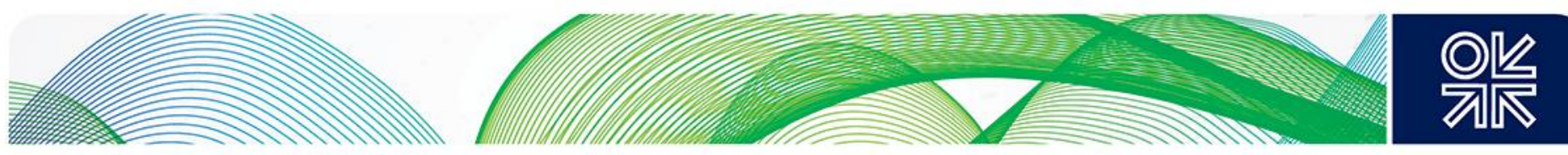

\section{Introduction}

The fall in the oil price since mid-2014 has caused steep declines in petroleum export revenue and, subsequently, fiscal deficits among Gulf Cooperation Council (GCC) states, making subsidy reforms an urgent priority. The impact in Kuwait was particularly severe due to the economy's dependence on hydrocarbons, which in 2014 generated $92 \%$ of the government's revenue and $55 \%$ of its GDP. After the oil price collapse from US $\$ 103 / \mathrm{barrel}$ (bl) in January 2014 to US $\$ 30 / \mathrm{bl}$ in January 2016, the government said revenues fell an estimated $75 \%$. Despite a history of strong fiscal surpluses and substantial foreign asset accumulation in its sovereign wealth funds (SWFs), by the end of the 20152016 fiscal year, Kuwait recorded a US $\$ 15.3$ billion budget deficit, its first in over 16 years. Official figures anticipate a total budget deficit of US $\$ 73$ billion over 2016-2019. Generally, reliance on an inherently volatile commodity renders any petro-dependent economy susceptible to boom and bust cycles. These cycles cause significant fiscal and real exchange rate volatility and impact economic activity directly through consumption, cost of living, and production, and indirectly through intermediates. Yet the impact on Kuwait's economy has been exacerbated by its very large fiscal commitments, rigid expenditures, and high subsidies. These subsidies are applied widely on various goods and services (including water and food). In the case of energy and hydrocarbons, the subsidies have an opportunity cost as they maintain the local price lower than the international shadow price, but they are also real expenditures as the subsidised local price is lower than production costs. Yet implementing fiscal and energy pricing reforms has proven particularly challenging. While policy debates on the need for energy pricing reform have been settled in many oil exporting countries, such debates still continue in Kuwait, obscuring the important debate on the mechanism of energy price reform. The latter is the subject of this paper, which quantifies the economic impacts of subsidy reform in a low petroleum price environment using an economy-wide modelling approach.

There are few studies of this type in the context of Kuwait and the GCC. Economic theory has widely accepted that subsidies, although pervasive, are distortionary (Plante, 2014), causing inefficient resource allocation and wasteful consumption. Subsidies also are inequitable; even when their objective is to expand energy access to the poor, their benefits tend to accrue to richer households due to their higher consumption levels. Nevertheless, empirical assessments of energy subsidy reform in developing countries offer inconclusive evidence; some suggest a negative impact on households' welfare (Arze Del Grando et al., 2012; Gahvari \& Taheripour, 2011), while others conclude welfare gains (Lin \& Li, 2012). Hartley \& Medlock III (2008) argue that national oil companies (NOCs), such as Kuwait Petroleum Company (KPC), are on average more inefficient than private oil companies, and that subsidising domestic consumption tends to increase this inefficiency. While BuShehri \& Wohlgenant (2012) illustrate in a micro model that reducing Kuwaiti electricity subsidies hurts welfare. Fattouh \& Mahadeva (2014) find that the alignment of residential electricity and water prices with market prices, coupled with cash transfers, encourages efficiency in consumption and generates a net welfare gain.

None of these studies examine the intermediate and macroeconomic implications of pricing reforms. Economy-wide models are best suited to offer such insights, but only a few such models of Kuwait's economy exist. Alsabah's (1985) ${ }^{1}$ computable general equilibrium (CGE) framework of Kuwait between 1979 and 1989 and the dynamic CGE model of Khorshid $(1990,1991)$ analyse the role of policies in driving Kuwait's long-term growth and the effects of domestic government expenditures on relative sectoral performance. Gelan (2014) utilises the International Food Policy Research Institute (IFPRI) standard CGE model (Lofgren et al., 2002) with Kuwaiti data from 2010, concluding that distributing cash transfers could reverse some of the contractionary effects and welfare losses brought on by reduced electricity subsidies. This model's high level of aggregation limits its ability to quantify distributional effects or supply-side technological changes. Collectively, these CGE assessments are outdated and do not reflect recent economic features or current petroleum market conditions.

${ }^{1}$ Unpublished doctoral dissertation. 

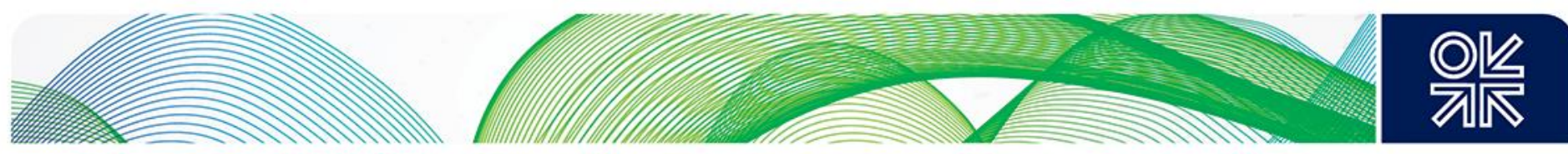

In assessing efficiency and economic policy, the omission of oligopoly and its collusive pricing behaviour from existing models of small economies like Kuwait is particularly important, since the assumption that policies directed to the advantage of one industry will have no effect on others is indefensible. It is well understood that competition induces innovation, so that short-run oligopoly (and monopoly) rent is destroyed in the long run by innovation. ${ }^{2}$ This idea has become central to modern research on economic growth (Segerstrom, Anant, \& Dinopoulos, 1990; Aghion \& Howitt, 1992; Aghion, Akcigit, \& Howitt, 2013). Oligopolies distort markets and prices, and their sustained rents engender strategic behaviours that detract from growth-enhancing innovation (Grossman \& Helpman, 2014). Incorporation of collusive oligopoly behaviour by Tyers (2014) suggests that the full exploitation of oligopoly market power in Australia would cause a reduction of real GDP by as much as a third in the long run. In advanced economies, this effect is moderated by pricing surveillance and price-cap regulation. Yet in resource exporters, oligopolies (in resources as well as other industries) play an additional role: as the appreciating exchange rate following resource booms causes declines in oligopolies' tradable input costs, their ensuing increased rents during booms and (usually subsidised) losses during busts further impair both the aggregate economic performance and the distribution of economic gains.

This paper aims to fill existing gaps in the literature by assessing and quantifying the potential effects of subsidy pricing reform in Kuwait following declines in petroleum export revenue through economywide modelling. To that end, the paper employs an economy-wide CGE framework that incorporates oligopoly behaviour by extending the approach of Asano \& Tyers (2015) and adapting it to Kuwait's economy. Importantly, this extends conventional CGE representation (which assumes firms are perfectly competitive) by incorporating imperfect competition that captures oligopolistic (and monopolistic) behaviour of collusive product pricing and by making explicit firms' profit maximisation pricing rules and economies of scale. At the same time, the model is designed to embody the unique features of Kuwait's economic structure, including its public sector dominance and interventions, its welfare system, capital inflows through its SWF, and its labour market characteristics, which are common across GCC states. An important contribution is the construction of a model database depicting these elements. The structure adopted enables the assessment of terms of trade shocks, real exchange rate volatility, and the changes in elasticities of demand that occur as sources of demand shift in response to commodity price shocks. In the context of the current literature on the Middle Eastern and North African economies, this model offers a unique perspective on oligopolistic behaviour, its regulation, and the management of both petroleum and non-petroleum oligopoly rents. It also explores the further effects of coordination between regulatory policies that target improved competition and the management of foreign labour contracts.

Section 2 offers a documentation of Kuwaiti energy pricing developments and economic features. Section 3 highlights key elements of the model database. Details of the constructed model follow in Section 4. Section 5 summarises empirical applications of the model, quantifying the transmission mechanism to the Kuwaiti economy of petroleum price volatility, subsidy reform, and possible competition reform. Simulations clarify the required adjustments, including the seldom discussed expatriate labour exit and the decline in oligopoly rents. They also show that the expansion of nonpetroleum tradables has limited but positive potential as a stabiliser of the economy. Section 6 reveals various tradeoffs, most notably between fiscal stabilisation and cost of living sustainability. It concludes that, although necessary, subsidy reform alone cannot provide the solution hoped for by the government, thus requires the addition of carefully designed mitigation measures and associated microeconomic reforms.

\footnotetext{
${ }^{2}$ The core idea is "creative destruction," which entails that innovation is induced by competitive forces and that, while any single innovation confers rents in the short run, subsequent competitive innovations "destroy" these rents, maintaining efficiency (Schumpeter, 1911; 1942: 82-83).
} 

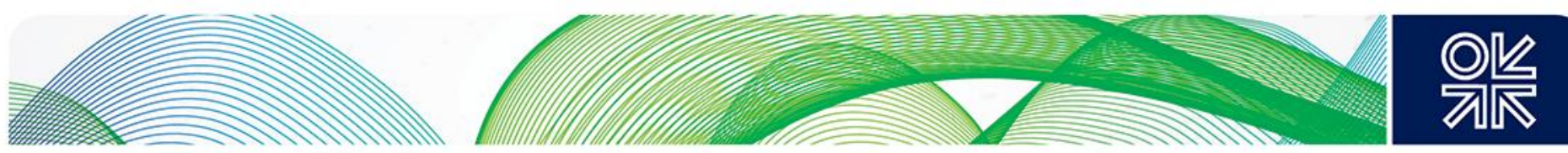

\section{Developments in Pricing Policy and Economic Features}

Energy subsidies in Kuwait have been pervasive and conspicuously high, even when compared to other petrostates - defined as countries whose hydrocarbon sales constitute at least half of export revenue and $25 \%$ of gross domestic product (GDP) and government revenue. ${ }^{3}$ A price gap approach comparison of domestic prices with their international shadow prices shows that Kuwait's subsidisation rate of energy products in 2014 , the most recently available, reached $87 \%$ (Figure 1 ). This subsidisation rate is expected to have dropped in 2015 due to a declining international oil price that year, but only marginally because high domestic energy consumption and the low domestic price did not change.

\section{Figure 1: Average subsidisation rates for 2014}

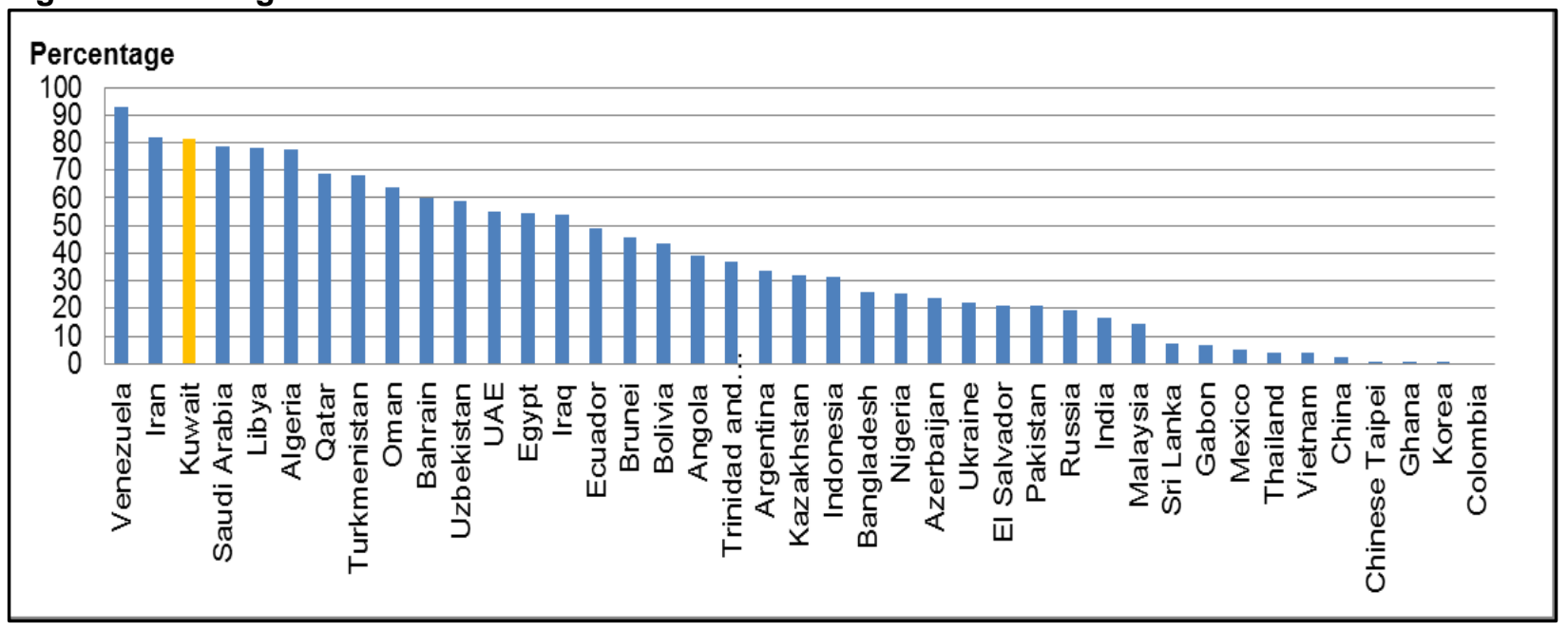

Source: Author's analysis using U.S. Energy Information Administration data.

Until mid-2016, Kuwaiti electricity prices were less than one-twentieth of generation costs and had not changed since 1990. Water, for which the desalination techniques use local hydrocarbon resources, has been offered at virtually no cost. Before August 2016, while many petrostates (such as Iran, Venezuela, and the GCC states) had increased local gasoline prices, Kuwait's prices remained unchanged for decades and were some of the lowest in the world. Artificially low domestic prices contributed to excessive consumption; in 2014, Kuwait was the world's sixth highest per capita energy consumer (World Bank, 2017). Figure 2 demonstrates the resulting fiscal pressures by comparing declining petroleum and, correspondingly, government revenues with increasing welfare and subsidy expenditures.

\footnotetext{
${ }^{3}$ This definition is set by the Canadian Centre for Policy Alternatives (CCPA). Colgan (2011) defines petrostates as ones with oil exports exceeding $10 \%$ of GDP.
} 

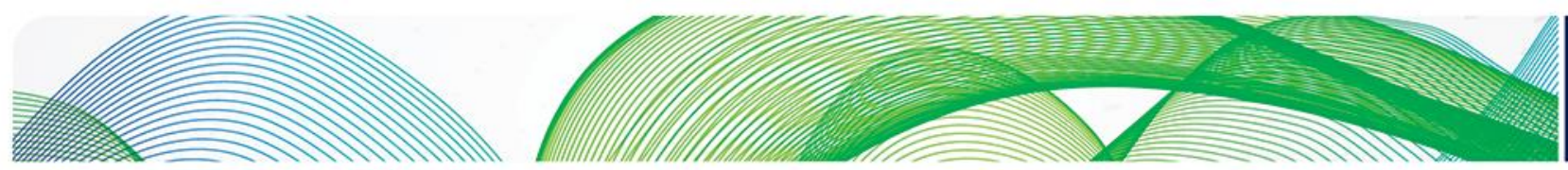

Figure 2: Energy and fuel services subsidies in Kuwait and oil export revenue 2004-2014

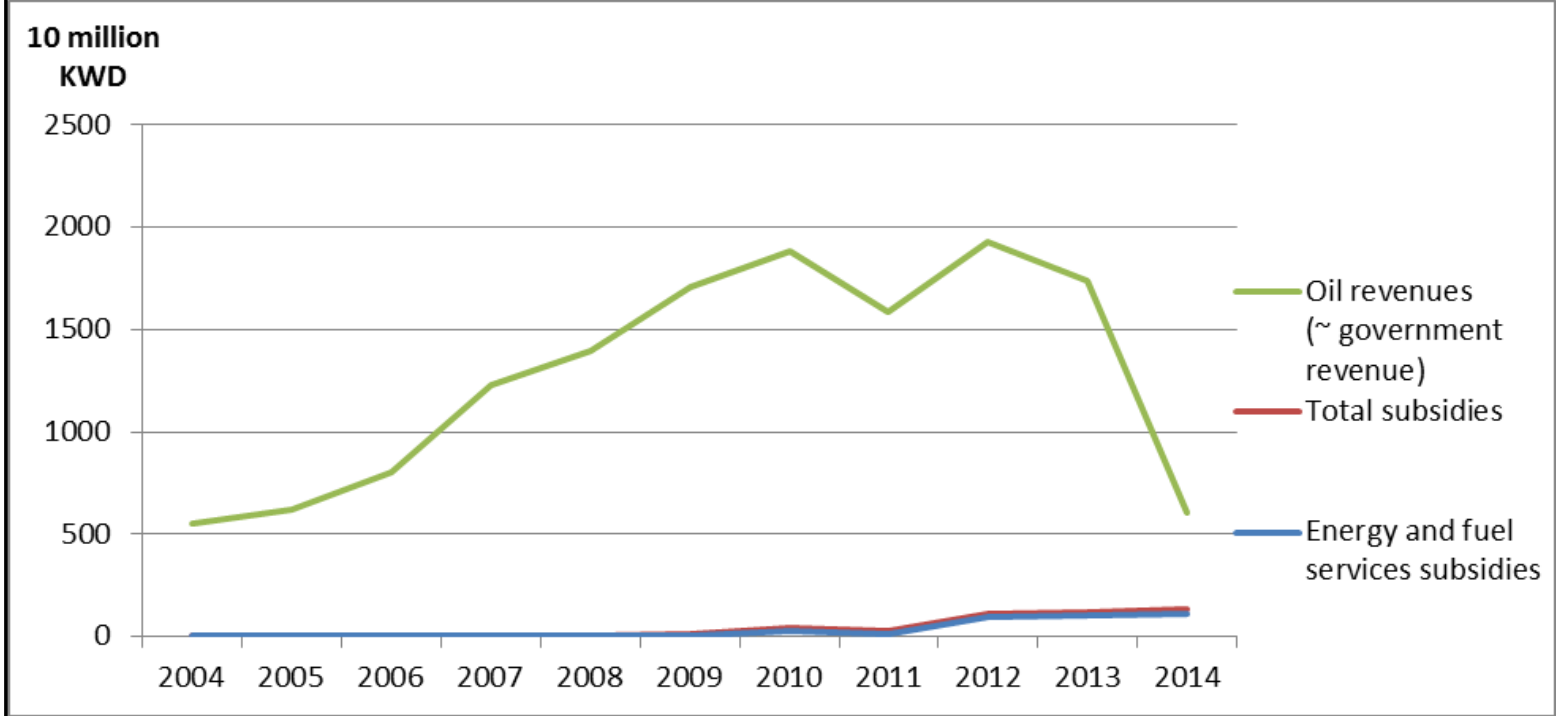

Source: Author's analysis using data from the Kuwait Government Finance Statistics- Ministry of Planning.

Against this backdrop, cutting energy subsidies at an accelerated pace has become a policy priority for the government; yet reform attempts have been unsuccessful or delayed due to political opposition. After various schemes were rejected, the National Assembly proposed 'excluding owner-occupied residences of Kuwaiti citizens' from any increase in electricity prices, effectively raising prices only for expatriates. In March-April 2016, the National Assembly proposed and approved a measure to raise electricity prices for residential use by expatriates from US $\$ 0.007$ progressively to US $\$ 0.05$ / kilowatt hour, and for commercial use from US $\$ 0.007$ to US $\$ 0.082 /$ kilowatt hour (“Al-Kuwait Tarfa'", 2016). Still, Kuwaiti energy price liberalisation lagged behind those of other GCC states. Kuwait was the last to reform its energy prices when in August 2016, the government, circumventing parliament, raised gasoline prices by $41-83 \%$, depending on octane levels, to the international shadow price effective from September. By that point, Kuwait had the lowest domestic gasoline prices globally and a US $\$ 15.3$ billion deficit for 2016. Members of the National Assembly challenged the energy price reform in court and requested hearings about petrol price increases, citing a 1995 law prohibiting the government from raising public service charges without parliamentary approval. Tensions culminated in an executive decree to dissolve the parliament in October 2016, after which the subsidies were not reinstated, but the proposed three-month price adjustment policy was not implemented. The government insisted its pricing reform would ease fiscal pressures, adjust economic inefficiencies, and address excessive energy consumption, arguing that any subsequent inflation would be muted. As opposition mounted, the new opposition-dominated parliament called for a draft law to abolish energy price hikes. Beyond these binary options, the economic impact of reforms has been little debated. Yet the Appeals Court decided in April 2017 to uphold the government's decision to raise energy prices ("Mu'akkida Sihhat", 2017).

Energy pricing reform in Kuwait is necessary due to its unique economic features and associated fiscal volatility. Like other petrostates, government revenues are volatile owing to its reliance on an inherently volatile commodity, while GDP is largely dependent on hydrocarbons with a relatively small nonpetroleum production sector. The decline in the international oil price reduces the cost of energy subsidies but only marginally because energy subsidies are large (being a function of a very low energy price and high levels of domestic consumption) and also because energy prices are lower than not only the international oil price but also their cost of production. Moreover, the economy's relatively unique features, discussed below, further exacerbate the impact of price volatility, posing serious policy conundrums. The following subsections summarise the qualitative context of these features, which were factored in the construction of the model of Kuwait's economy. 

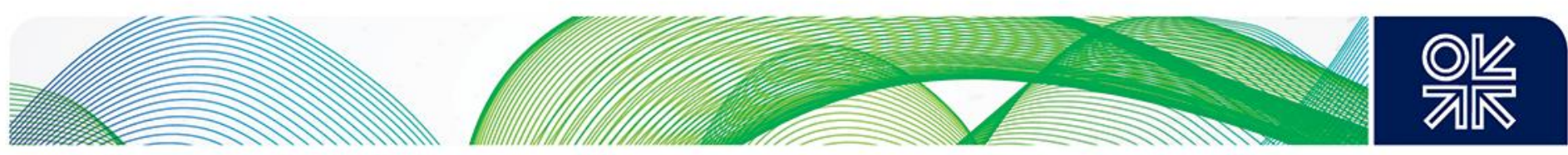

\subsection{Dominance of the Public Sector}

Besides the nominally independent but publicly-owned hydrocarbon industry, the public sector is the employer of choice for Kuwaiti nationals and it dominates the economy. In 2014, the public sector generated over $65 \%$ of GDP, compared with a private sector share that has ranged between $21 \%$ (1989) and $41 \%(2010)$. This structure dates back to early developments of modern-day Kuwait following the oil price spikes of the 1970s. It contributes to large and rigid government expenditures, impacting total welfare. As is well known in economic literature, publicly-owned firms are monitored by the government and managed so as to favour domestic consumer surplus and domestic employment (Hartley \& Medlock III, 2008; Hartley \& Trengove, 1986). In 2010 (under law 37/2010) the Kuwaiti government adopted its "Privatization Plan" with the aim of increasing the role of the private sector across different industries through various Five-Year Development Plans, the most recent beginning in $2015 .{ }^{4}$ Yet there is still a gap between the plan's stated objectives and economic realities, as the overall structure and size of the private sector have remained largely unchanged.

\subsection{Fiscal Rigidities}

During periods of low petroleum prices, adjusting Kuwait's fiscal gap between revenue and expenditure becomes difficult due to the following factors.

\section{Rigid government expenditure}

Approximately $80 \%$ of government expenditure is current expenditure, half of which funds the public sector wage bill. The size of this bill reflects preferences of Kuwaiti nationals for working in secure, permanent jobs with wages largely exceeding those in the private sector. This preference also reflects the constitutional right - which it is the obligation of the government to meet - of each Kuwaiti citizen to employment. Public employment has often been viewed as part of the so-called petroleum era 'social contract' (i.e., the distribution of resource rents in lieu of political obedience).

\section{Generous welfare transfers}

In 2014, transfers and subsidies to households and firms represented more than half of the government's total spending. They span a wide range of products and services, including energy. ${ }^{5}$ Such large commitments have reduced the scope and flexibility of other public expenditures, which are rigid in light of the opposition to any reduction of public transfers. Generous welfare payments are at the core of the Kuwaiti political economy, an arrangement deeper than the so-called petroleum era 'social contract'. For some of the politically active constituency, reform contradicts the state's historic role in distributing petro-rents to its citizens, the ultimate owners of the resource. Accordingly, all official plans to reduce welfare benefits were ignored prior to the reforms that followed the fiscal challenges of 2016.

\section{Negligible tax revenue}

Tax revenue constitutes an insignificant share of less than $1 \%$ of the overall revenue side of the government budget, despite discussions of tax reform and the imposition of income tax, especially on expatriate workers. Taxes are applied at almost negligible rates on labour income. Negligible rates were also applied for decades on the profits of Kuwaiti firms. By contrast, wholly or majority-owned foreign firms, a small proportion of the total, have faced internationally comparable (i.e., higher) tax rates, in some instances as high as $55 \%$. Yet most of them paid local rates by operating through local partnerships. Further, all publicly traded and closed Kuwaiti shareholding companies pay $1 \%$ tax on annual net profit as zakat, the almsgiving tax mandated by Islamic law. ${ }^{6}$ Shareholding activities pay

\footnotetext{
${ }^{4}$ The Ministry of Planning and Development's five-year development plans were first adopted in 1984-1985.

${ }^{5}$ El-Katiri, Fattouh, and Segal (2011) detail Kuwaiti welfare transfers.

${ }^{6}$ This tax, mandated by law No. 46 of 2006 effective December 2007, is calculated on annual net profit before deductions for the Board of Directors remuneration and any contributions to the Kuwait Foundation for the Advancement of Sciences, National Labour Support Tax, and any other donations or grants.
} 

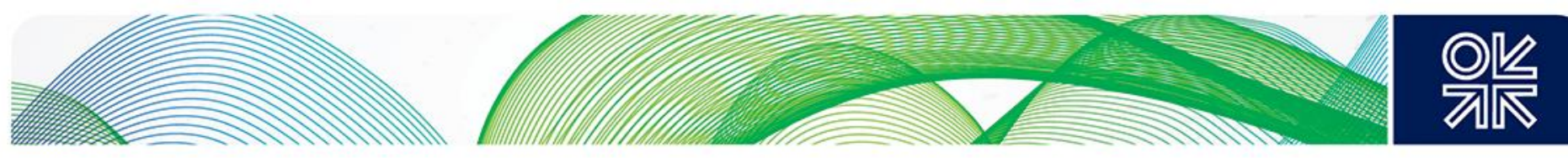

$1 \%$ of total profits in support of scientific research undertaken by the Kuwait Foundation for the Advancement of Science (KFAS). All listed companies also pay the National Labor Support Tax, computed at $2.5 \%$ of the annual net profits prior to deductions, to support the employment of Kuwaiti nationals to work in the private sector. ${ }^{7}$ As part of fiscal reforms in 2016, the government approved the introduction of a $10 \%$ corporate tax rate on profits of Kuwaiti firms and multinationals' permanent establishments (Al-Sennari, 2016). A value-added tax (VAT) of $5 \%$ is expected to be imposed in 2018 , in line with a GCC-wide agreement. As another means to diversify government revenue, in 2017 the parliament proposed imposing a $5 \%$ tax on foreign remittances, which equaled $5 \%$ of GDP and $18 \%$ of government revenue in 2015 (with estimates as high as 35\% in 2016) (Farouq \& Moussa, 2017).

\subsection{Labour Market}

Although omitted from much of the associated literature, the composition of the labour market is particularly important for small economies like Kuwait (and the GCC) that are dependent on temporary expatriate labour. This composition has various economic, social, and political implications. Also, its flexibility, owing to immigration and temporary worker policies, is an essential safety valve in the face of export volatility. Table 1 presents the breakdown of the Kuwait's labour force.

Table 1: Breakdown of Kuwait's labour force by nationality and sector, January 2015

\begin{tabular}{|l|c|c|c|c|c|c|c|}
\hline \multirow{2}{*}{ Sector } & \multicolumn{2}{|c|}{ Kuwaitis } & \multicolumn{2}{c|}{ Non-Kuwaitis } & \multicolumn{2}{c|}{ Total } \\
\cline { 2 - 7 } & $\begin{array}{c}\text { Numbers } \\
\text { of } \\
\text { employees }\end{array}$ & $\begin{array}{c}\text { Percentage } \\
\text { of total by } \\
\text { sector }\end{array}$ & $\begin{array}{c}\text { Numbers } \\
\text { of } \\
\text { employees }\end{array}$ & $\begin{array}{c}\text { Percentage } \\
\text { of the total } \\
\text { labour } \\
\text { force }\end{array}$ & $\begin{array}{c}\text { Numbers } \\
\text { of } \\
\text { employees }\end{array}$ & $\begin{array}{c}\text { Percentage } \\
\text { of the total } \\
\text { labour } \\
\text { force }\end{array}$ \\
\hline Public & 326,271 & $70 \%$ & 139,594 & $30 \%$ & 465,865 & $100 \%$ \\
\hline Private & 93,195 & $5 \%$ & $1,934,240$ & $95 \%$ & $2,027,435$ & $100 \%$ \\
\hline Unemployed & 10,692 & $33 \%$ & 21,255 & $67 \%$ & 31,947 & $100 \%$ \\
\hline Total & 430,158 & $17 \%$ & $2,095,089$ & $83 \%$ & $2,525,247$ & $100 \%$ \\
\hline
\end{tabular}

Source: Author's analysis using Public Authority for Civil Information (PACl) - Population and labour force data, January 2015.

The composition revealed by the data has important sectoral, wage, and labour mobility implications. Expatriates comprise $83 \%$ of Kuwait's labour force. Overall, $77 \%$ of national workers are employed by the bloated public sector, which has high disguised unemployment. Nonetheless, highly subsidised government-owned industries, such as electricity, employ mostly Kuwaitis. Public sector positions prioritise indigenous employment and offer salaries exceeding those in the private sector for similar levels of education and technical training (Al-Kaisi, 1993). To increase the participation rate of nationals in the private sector, the government offers private firms allowances to equalise Kuwaiti workers' wages with public sector wages; however, the private sector remains dominated by expatriates, who hold $95 \%$ of its jobs. Further, data from PACl show that more than three quarters of expatriate labour occupies low-skilled positions in construction, sales, machinery, and trades. Expatriate wages generally are lower than public-sector Kuwaiti labour wages, constituting $70 \%$ of total wages, the majority of which are transferred abroad as remittances. It is estimated that a total of US $\$ 15$ billion were transferred in 2016, mostly to India, Egypt, and the Philippines. Importantly, expatriates have flexible labour contracts tied to employer-sponsored visitor working visas through the kafāla system. Their employment level is thus endogenous, reacting to shocks in the economy.

\subsection{Concentration in Industries and Oligopoly}

It is not surprising that the high levels of minimum efficient scale delivered by modern technology and the smallness of the GCC economies should lead to the emergence of oligopolies or monopolised industries, particularly in protected services. Nonetheless, it is likely that such structures of imperfect

${ }^{7}$ This tax, mandated by law 19 of 2000 excludes GCC companies that do not have operations in Kuwait. 

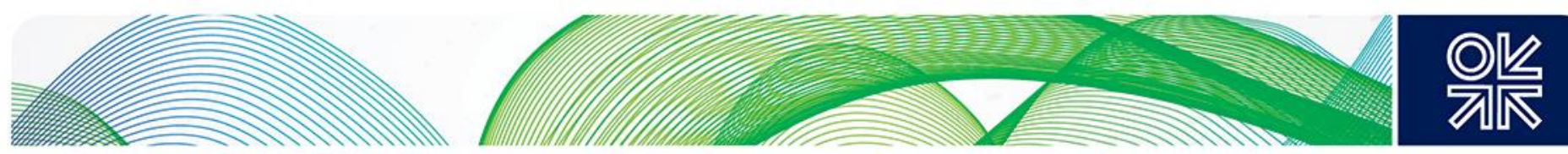

competition are highly distortionary and, therefore, limit economic performance. Using data on listed companies from the Kuwaiti Stock Exchange, Figure 3 depicts the concentration of industries' revenue within a few companies.

\section{Figure 3: Cumulative Kuwaiti firm shares of industry revenue}

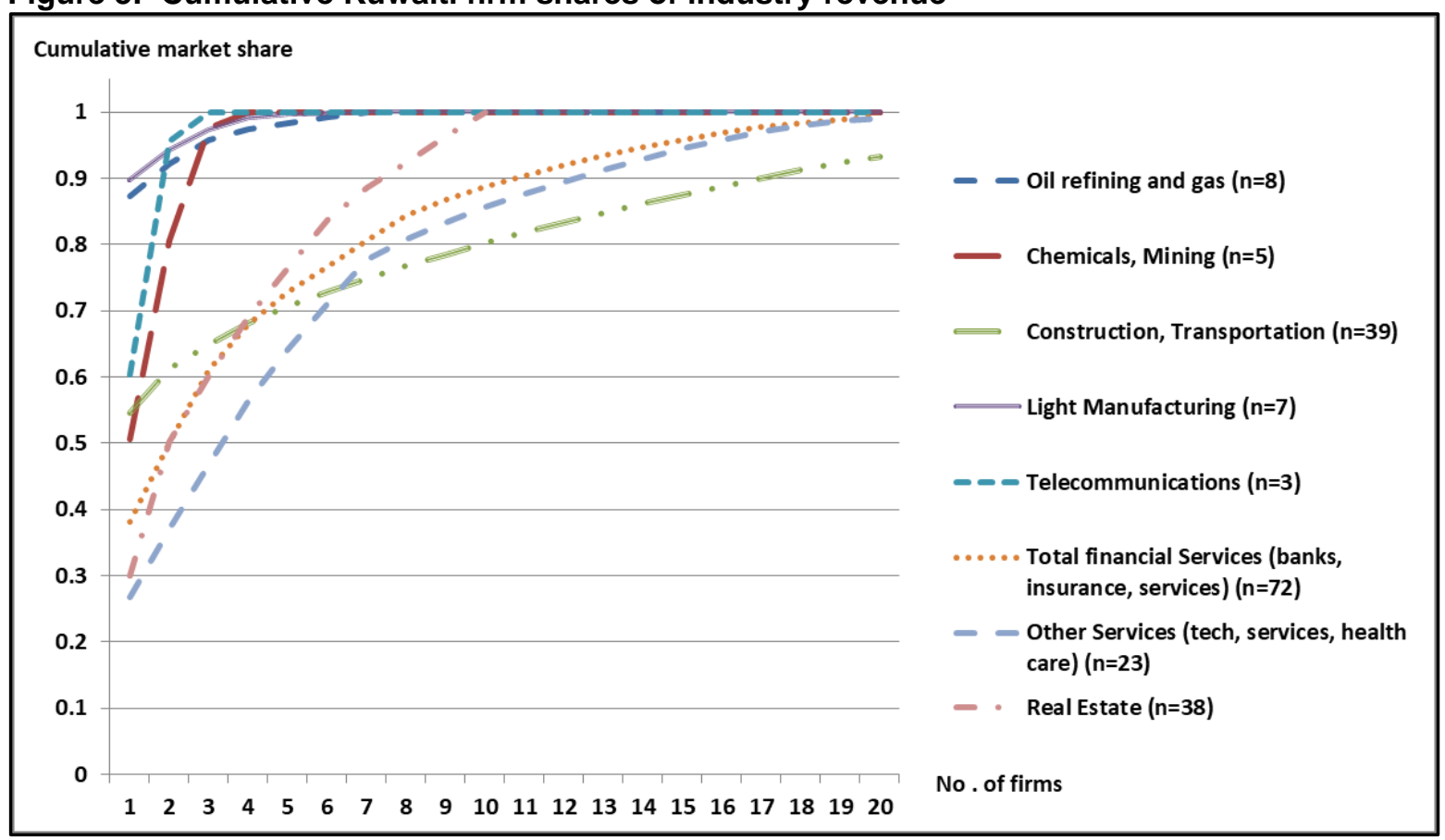

Source: Author's analysis using data from the Kuwaiti Stock Exchange.

Note: The vertical axis shows the cumulative share using revenue data except for financial services, which is calculated based on net profit (due to data limitations). The horizontal axis shows the number of total firms $n$.

The pervasiveness of oligopolies, identified by high levels of concentration within a few industries, is evident when examining listed firms' revenue across industries, as shown in Figure 3 . For instance, of the 72 listed financial services firms, the top two account for 50\% of the industry's total market net profit. Similar industry concentration trends emerge when examining listed firms' market capitalisation. It is not surprising that a small economy like Kuwait should have its markets supplied by monopolies and oligopolies. Kuwait has no significant agriculture, and its domestic demand is small compared with minimum efficient scale in its Manufacturing and Network Services industries, which Kuwait exports on a small scale. Yet, the data imply distortions across all listed industries. Importantly, although data on capital for unlisted companies are unavailable, similar concentration trends are evident when examining revenue of an aggregate representative data of all (listed and unlisted) Kuwaiti companies across all industries. Kuwait's Ministry of Commerce and Industry has passed Law 10/2007 for the Protection of Competition, establishing the Kuwaiti Competition Protection Authority to reduce imperfect competition. Despite its limited role in Kuwait to date, the very existence of this agency points to the prevalence of oligopoly in the economy. Notably, similar regulatory agencies operate actively in many advanced economies to advance competition. Similarly, Kuwait's "Privatization Plan" (2010) includes objectives to increase competitive pricing across industries and to reduce oligopolies and oligopolistic collusion.

\subsection{Kuwait Investment Authority (KIA)}

One of the most important factors in Kuwait's historical ability to weather volatile petroleum prices is its foreign investments held by the country's SWFs, known as the Kuwait Investment Authority (KIA). Generally, SWFs are government-owned investment funds commonly established during periods of 

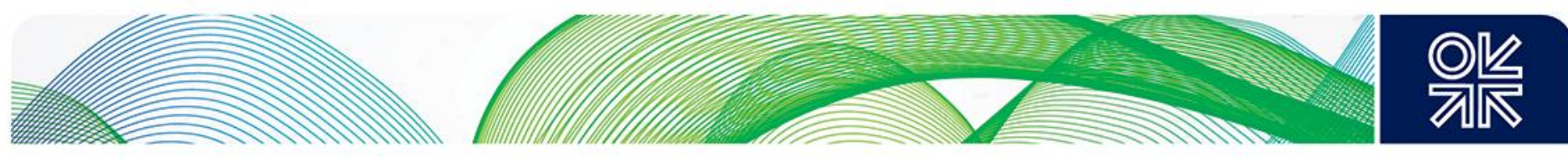

government surplus. ${ }^{8}$ They are typically created to serve as stabilisation funds, savings funds, pension reserve funds, or reserve investment corporations. Some countries have more than one fund, and some funds (like the KIA) have multiple objectives. In resource-rich states, they are established to reduce the impact of volatile resource windfalls on government revenue and exchange rates. SWFs also offer a mechanism to reinforce fiscal discipline through rules mandating recurrent contributions to the funds and withdrawal limitations from them. They also offer a mechanism to diversify government portfolios across sectors, regions, assets and risk profiles. In Kuwait specifically, the KIA was established in 1953, 8 years prior to independence, and is the oldest country-owned SWF in the world. The KIA manages two funds. One, the Future Generations Fund, is a long-term intergenerational fund established as an alternative source of government revenue to petroleum. ${ }^{9}$ The second, the General Reserves Fund (GRF), serves a macro-stabilisation objective, offering fiscal rebalancing through inflows to and from the fund.

Importantly, the KIA is an important institutional feature of the Kuwaiti economy because the GRF has been successful in acting as a financing alternative to petroleum revenue shortages, enabling the Kuwaiti economy to manage petroleum price volatility, as follows. Either budget surpluses are invested in the GRF or funds are withdrawn from it to smooth out short-run governmental expenditures during deficits, thus shielding the economy from the negative impacts of petroleum price volatility. Another factor in the success of the KIA is that both funds employ diversified investment strategies focusing on investments with different time horizons and in various industries, though largely away from petroleum, and across various geographical regions. Despite limited available data about the KIA, there are rules requiring returns to be reinvested, irrespective of oil price volatility. Due to these factors, Kuwait has acquired a substantial and diversified international asset portfolio, estimated at $\$ 592$ billion. ${ }^{10}$ As such, an important feature to model concerns flows to and from the KIA.

\section{The Social Accounting Matrix}

A key component of applying the CGE framework economy-wide is the use of an appropriate database to which the model can be calibrated. An ideal framework for CGE models is a Social Accounting Matrix (SAM) depicting all sectors in an economy and the interactions between them within a given period. The constructed SAM reflects features of Kuwait's economy drawing from various official data sources for 2013 (the most recently available). Appendix A details the SAM construction. The constructed SAM aggregates official data for 57 economic sectors to 14, of which 6 are energy or energy-intensive industries. It also disaggregates factor rewards to seven primary factors: physical capital, skilled Kuwaiti labour, skilled non-Kuwaiti labour, unskilled Kuwaiti labour, unskilled non-Kuwaiti labour, arable land, and energy resources (petroleum in the ground). Factor shares and input output coefficients from these 2013 data are combined with detailed bilateral trade, transport, and trade protection data (such as tariffs), as well as country-specific data such as national accounts and balance of payments. The SAM reveals key structural elements of the Kuwaiti economy, which Table 2 depicts.

\footnotetext{
${ }^{8}$ For further reading, see: Davis et al., 2001; Allen \& Caruana, 2008; Das et al., 2009; Collier, Spence, van der Ploeg \& Venables, 2010; van der Ploeg \& Venables, 2012.

${ }^{9}$ The government is mandated to invest $25 \%$ (reduced to the pre-2012 share of $10 \%$ in the wake of the oil price collapse) of all petroleum export revenue in this fund.

${ }^{10}$ Kuwaiti Law No. 47 of 1982, Clauses 5 and 8-9, bind the KIA to nondisclosure, making data on the KIA confidential. Detailed data are provided to the Council of Ministers with strict restrictions on public access.
} 

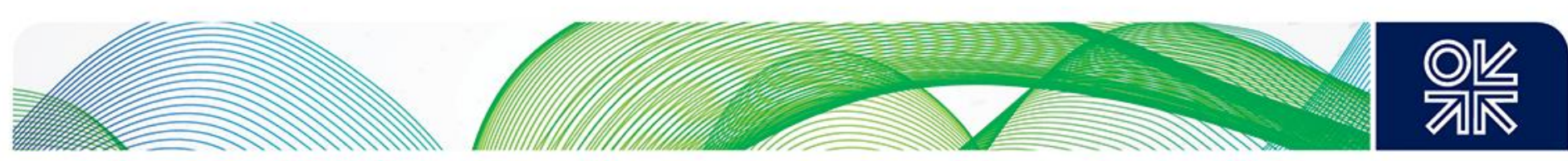

Table 2: Economic structural elements 2013

\begin{tabular}{|l|c|c|c|c|}
\hline Sector/ Percentage & $\begin{array}{c}\text { Share of } \\
\text { GDPF }^{*}\end{array}$ & $\begin{array}{c}\text { Share of total } \\
\text { exports }\end{array}$ & $\begin{array}{c}\text { Export share of } \\
\text { output }\end{array}$ & $\begin{array}{c}\text { Net exports } \\
\text { over output }\end{array}$ \\
\hline 1 Agriculture & 0.3 & 0.0 & 1.3 & -63.3 \\
\hline 2 Mining & 1.4 & 0.0 & 0.0 & 0.0 \\
\hline 3 Crude oil & 48.9 & 42.1 & 50.5 & 50.3 \\
\hline 4 Gas and petro-services & 0.9 & 1.3 & 50.5 & 50.3 \\
\hline 5 Oil refining & 5.4 & 38.6 & 72.6 & 72.2 \\
\hline 6 Chemical & 1.1 & 3.4 & 37.4 & -1.7 \\
\hline 7 Light manufacturing & 0.8 & 0.4 & 4.1 & -56.0 \\
\hline 8 Heavy manufacturing & 0.8 & 1.9 & 8.1 & -72.0 \\
\hline 9 Electricity & 0.6 & 0.0 & 0.0 & 0.0 \\
\hline 10 Other network services & 4.6 & 4.6 & 32.3 & 31.4 \\
\hline 11 Construction & 2.2 & 0.0 & 0.0 & 0.0 \\
\hline 12 Transport & 3.4 & 5.7 & 38.9 & 14.1 \\
\hline 13 Financial services & 7.8 & 0.7 & 4.1 & -1.3 \\
\hline 14 Other services & 21.7 & 1.2 & 1.8 & -15.6 \\
\hline
\end{tabular}

* GDPFC is GDP at factor cost, which is the sum of value added in each industry.

Source: Model database (social accounting matrix) constructed by author for 2013.

The data reveal dynamics pertinent to assessing impacts of oil price shocks and pricing reforms. After hydrocarbons, Other Services are the second-highest value-adding industry, employing mostly expatriate labour. The Chemicals, Other Network Services, and Transport industries generate $14 \%$ of exports, each exporting approximately one-third of its output. Data on these industries indicate that Kuwait has some existing expandable non-petroleum exportation capacity, and point to a heavy indirect effect through imported intermediate inputs (which form a large part of all intermediates).

Crucial to interpreting the results are factor shares of value added in each industry, shown in Table 3.

Table 3: Factor intensity in value added per industry 2013

\begin{tabular}{|l|c|c|c|c|c|c|c|}
\hline $\begin{array}{l}\text { Industry/ } \\
\text { Percentage }\end{array}$ & $\begin{array}{c}\text { Physical } \\
\text { capital }\end{array}$ & $\begin{array}{c}\text { Kuwaiti } \\
\text { unskilled } \\
\text { labour }\end{array}$ & $\begin{array}{c}\text { Kuwaiti } \\
\text { skilled } \\
\text { labour }\end{array}$ & $\begin{array}{c}\text { Expatriate } \\
\text { unskilled } \\
\text { labour }\end{array}$ & $\begin{array}{c}\text { Expatriate } \\
\text { skilled } \\
\text { labour }\end{array}$ & $\begin{array}{c}\text { Arable } \\
\text { land }\end{array}$ & $\begin{array}{c}\text { Natural } \\
\text { resources }\end{array}$ \\
\hline 1 Agriculture & 35.1 & 0.5 & 0.4 & 5.7 & 2.4 & 41.4 & 14.5 \\
\hline 2 Mining & 9.3 & 12.8 & 29.8 & 2.8 & 1.9 & 1.1 & 42.3 \\
\hline 3 Crude oil & 13.1 & 4.2 & 9.9 & 0.4 & 0.3 & 0.1 & 72.0 \\
\hline $\begin{array}{l}\text { 4 Gas and petro- } \\
\text { services }\end{array}$ & 25.7 & 15.1 & 18.4 & 1.1 & 0.7 & 0.1 & 39.0 \\
\hline 5 Oil refining & 86.6 & 5.4 & 6.6 & 0.8 & 0.5 & 0.0 & 0.0 \\
\hline 6 Chemical & 76.8 & 4.1 & 4.1 & 9.5 & 5.6 & 0.0 & 0.0 \\
\hline $\begin{array}{l}\text { 7 Light } \\
\text { manufacturing }\end{array}$ & 55.4 & 10.0 & 10.0 & 18.4 & 6.1 & 0.0 & 0.0 \\
\hline $\begin{array}{l}\text { 8 Heavy } \\
\text { manufacturing }\end{array}$ & 52.6 & 10.7 & 10.7 & 19.6 & 6.5 & 0.0 & 0.0 \\
\hline 9 Electricity & 86.1 & 7.6 & 4.9 & 0.8 & 0.5 & 0.0 & 0.0 \\
\hline $\begin{array}{l}\text { 10 Other network } \\
\text { services }\end{array}$ & 65.4 & 6.9 & 4.2 & 4.4 & 3.0 & 16.1 & 0.0 \\
\hline 11 Construction & 32.2 & 9.5 & 4.1 & 38.0 & 16.3 & 0.0 & 0.0 \\
\hline 12 Transport & 52.9 & 10.6 & 3.5 & 28.0 & 4.9 & 0.0 & 0.0 \\
\hline 13 Financial services & 31.2 & 8.3 & 19.3 & 14.5 & 26.8 & 0.0 & 0.0 \\
\hline 14 Other services & 17.0 & 1.7 & 14.9 & 41.8 & 24.6 & 0.0 & 0.0 \\
\hline
\end{tabular}

Source: Author's CGE model database (SAM) constructed for 2013. 

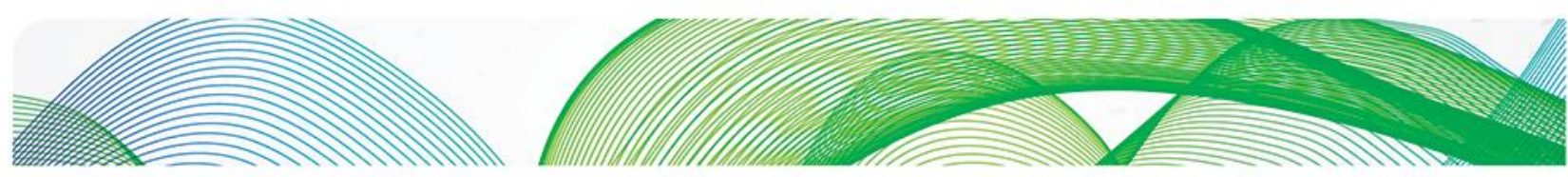

Oil Refining, Electricity, Chemicals, and Network Services have the highest capital intensity. The tradable Manufacturing and nontradable Other Services and Construction industries have the highest labour intensity. These relative intensities determine changes in factor rewards following commodity price shocks, thereby driving factor relocation and output across industries.

Per the SAM data, the reported consumption subsidies, seen in the official Input-Output table, are approximately $8 \%$ of value-added activities. Their value combined with government reported industry subsidies (i.e., payments from the government to industry for intermediate consumption) in 2013 was US $\$ 8,670$ million, as Table 4 details. These figures exclude the shadow price and costs of virtually free energy inputs (such as petroleum and natural gas provided to the electricity and water industries).

Table 4: Reported industry and consumption subsidies 2013

\begin{tabular}{|l|c|}
\hline Demand sector or source & Subsidies (million USD) \\
\hline 1 Agriculture & 255.6 \\
\hline 2 Mining & 8.14 \\
\hline 3 Crude oil & 138.3 \\
\hline 4 Gas and petro-services & 1.5 \\
\hline 5 Oil refining & 731.9 \\
\hline 6 Chemical & 890.4 \\
\hline 7 Light manufacturing & 194.4 \\
\hline 8 Heavy manufacturing & 125.2 \\
\hline 9 Electricity & 439.3 \\
\hline 10 Other network services & 789 \\
\hline 11 Construction & 184.7 \\
\hline 12 Transport & 198 \\
\hline 13 Financial services & 142.4 \\
\hline 14 Other services & 1232.4 \\
\hline Household consumption subsidies & $3,277.4$ \\
\hline Investment and inventory consumption subsidies & 61.5 \\
\hline TOTAL reported consumption subsidies & 8,670 \\
\hline
\end{tabular}

Source: Author's CGE model database (SAM) constructed for 2013.

As the flows in constructed SAM do not reveal details of intra-sectoral industrial structure, additional data are needed to calibrate the model to the SAM. The calibration process involves the use of indices and parameters to represent imperfect competition, including an index that represents the "effective" number of strategically interacting firms in each sector. This determination of number is informed by analysing the levels of industrial concentration (described in Section 2.4. above) and the ownership structure (private vs. public) of firms. Additional information is also needed on pure profits, fixed costs, and minimum efficient scale for each industry. ${ }^{11}$

\section{Modelling the Kuwaiti Economy}

The model is implemented using the GEMPACK (General Equilibrium Modelling PACKage) modelling software. It is a development of that described in Shehabi (2017). The following offers an overview of the model, with details consigned to Appendix B.

\subsection{Genesis and Extensions}

Key motivations behind the chosen model structure are: the importance of oligopolistic behaviour; the potential role of pricing regulation in small economies in moderating the impact of petroleum volatility

\footnotetext{
${ }^{11}$ Additional information on the database and the calibration of oligopoly parameters and pure profits are available on reques from the author.
} 

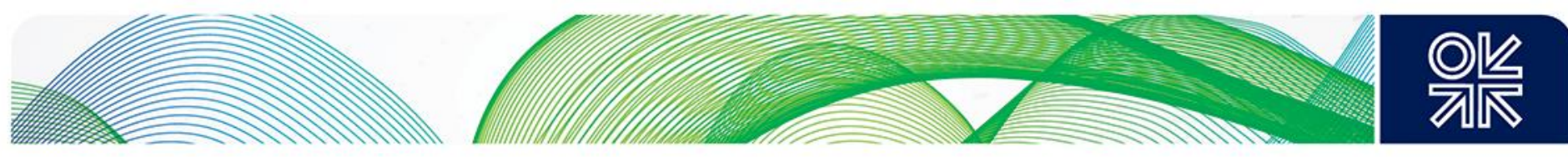

on employment and overall economic activity; and the need to compare the short and long-term implications of, and interactions amongst, energy, trade, labour, and macroeconomic policies. The model incorporates core features of conventional CGE modelling, building on Asano \& Tyers (2015). The "almost small" characterisation of the modeled economy follows Harris (1984) and Dixon et al. (1982) and its openness extends to financial markets via endogenous saving and investment and open capital and current accounts. These assumptions are essential in the case of Kuwait, which has a small economy that is highly dependent on trade (including imports in markets where it is a price taker) and on international financial flows. Like that of Balistreri \& Markusen (2009), the model includes the standard CGE modelling feature of Armington ${ }^{12}$ elasticities of subnational product differentiation between home and foreign products, with home products generally having higher elasticities of substitution than international ones. This feature implies important relationships between industrial policy, the terms of trade, and the real exchange rate.

Financial flows and real exchange rate changes are endogenous, while external economic conditions, such as yields on investments abroad and global petroleum market trends, are exogenous and can be shocked in model simulations. The real exchange rate represents the common currency ratio of the home price of a bundle of (traded and non-traded) goods and services at home relative to that abroad, and is modeled accordingly. Therefore, it is sensitive to both the performance of the traded industries as well as non-traded services sector. The model adopts neoclassical features in characterising consumption preferences and the variable costs of production, including optimising representative agent behaviour, full input substitutability, and flexible product and factor prices. It accounts for the key structural details that characterise the Kuwait economy (Ocampo, Rada, \& Taylor, 2009). The unique Kuwaiti economic features captured are as follows.

\section{Public sector}

Given that KPC and the electricity company operate as large and nominally independent corporations, they are represented as separate monopoly firms with their own factor demand and output. The government is treated as the residual owner of additional rent payments (profits) after payments to fixed and variable capital and labour.

\section{Taxes and subsidies}

Fiscal rigidities are included in the model through a full representation of government accounts and expanded consumption subsidies and taxes (both direct and indirect). Although in Kuwait some of these government revenue sources are not active, the modelling includes them to enable the analysis of potential tax reforms. The collection of petroleum export revenue appears as a quasi-tax payment, used to infer a corporate tax rate. Subsidies are represented by negative consumption and corporate taxes.

\section{Flexibility of labour contracts}

The model expands industries' production functions to include four labour types that are differentiated by nationality (i.e., Kuwaiti and expatriate) and by skill (i.e., skilled and unskilled). To reflect the Kuwaiti labour market's segmentation, wage and mobility rigidities in the labour market are assumed, especially pertaining to public sector employment and low-skill wages.

\section{Oligopolistic industries}

Uniquely, in a departure from conventional CGE modelling, the model represents oligopoly with behavioural structure from Asano \& Tyers (2015), which is based on earlier work done by Tyers (2014), Gunasekera \& Tyers (1990), Harris (1984), Horridge (1987), and Tyers (2005). This representation is

\footnotetext{
${ }^{12}$ According to Armington's (1969) theory, home and foreign goods (i.e., imports) are imperfect substitutes in the aggregate production of a given industry. Thus, tariff reduction or exchange rate appreciations will make home goods relatively less expensive, thus shifting the composition of the aggregate output towards imports. The Armington specification in the model allows the economy to produce, import, and export products of the same sector.
} 

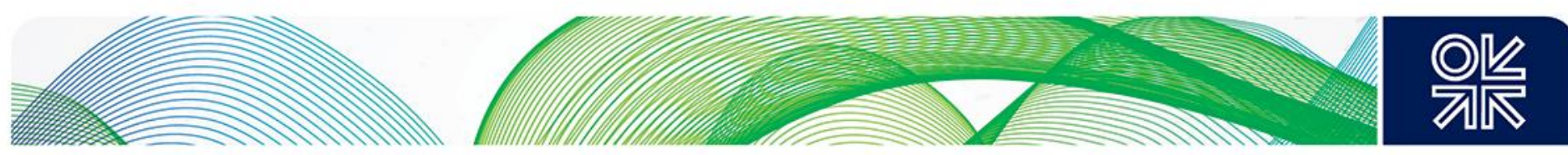

based on firms' profit maximisation behaviour and is chosen because it enables the incorporation of various realistic features of Kuwaiti oligopolistic (and monopolistic) industries and targeted regulatory surveillance. ${ }^{13}$ This representation emphasises oligopoly rents in the spirit of Blanchard \& Giavazzi (2003) who, in a closed-economy general equilibrium setting, found that increased competition is beneficial to an economy because it leads firms to lower their markups, in turn lowering prices and increasing output and exports economy-wide. In all economic sectors, private and state-owned firms are oligopolistic in their product pricing behaviour, with each colluding on prices at various levels. Incorporating imperfect competition requires additional data to calibrate the model and renders the calibration process more complex. To incorporate in the model the realistic feature that larger firms are subject to regulation and pricing surveillance, data ${ }^{14}$ are analysed on industry structure, conduct, and performance to determine cost and pricing behaviour, represented in the model through parameterisation. Importantly, collusion and other values can be set to represent a degree of regulatory surveillance or price cap enforcement by the Kuwaiti Competition Protection Authority.

\section{KIA}

The model takes into account external financial flows, primarily flows to and from the KIA. These mimic, to the extent possible, the KIA's role as a source of government funds following petroleum price shocks.

\subsection{Model Structure}

Two regions (Kuwait and the Rest of the World) are incorporated in a comparative static framework. Yet the framework employs different closures (described below) to differentiate short and long-run dynamics. As modeled, the Kuwait economy has one representative household that consumes home and imported goods, supplies indigenous and expatriate labour and skill and owns physical capital. Firms in 14 industries rent capital and hire workers, supplying products and services to meet five demand sources: final, intermediate, investment, government, and foreign. The government earns petroleum revenue, collects taxes and transfers subsidy and welfare payments to firms and Kuwaiti households. The model represents financial agents who manage portfolios of domestic and foreign assets impacting the inflow and outflow of financial investments. Employment contracts are flexible for each labour type (and can be fixed in model applications). Exogenous external economic conditions, such as export demand and foreign investment yields, are readily shocked in applications of the model. All in all, there are 3,820 components representing 247 equation blocks, with 3,606 separate endogenous variables.

\subsubsection{Demand side}

This model makes conventional assumptions about the consumption of home products in each sector, whereby domestic products are differentiated by variety via constant elasticity of substitution (CES) nests. These local products are further differentiated also through CES nests from a given number of $n$ of imported foreign varieties. Each local industry faces demands for its output from five sources: final demand $(F)$, investment demand $(V)$, government demand $(G)$, intermediate demand $(I)$, and export demand $(X)$. Accordingly, firms in a given industry $i$ face a downward-sloping demand curve with an elasticity of demand $\left(\varepsilon_{i}\right)$ that depends on the weighted average of the elasticities of demand in these five markets, based on each demand source's elasticity multiplied by that source's share in the demand for industry I home products, as follows:

$\varepsilon_{i}=S_{i}^{F} \varepsilon_{i}^{F}+S_{i}^{V} \varepsilon_{i}^{V}+S_{i}^{I} \varepsilon_{i}^{I}+S_{i}^{X} \varepsilon_{i}^{X}+S_{i}^{G} \varepsilon_{i}^{G} \quad \forall i$

\footnotetext{
${ }^{13}$ There are alternative formulations of imperfect competition used in economy-wide CGE models. While there is no one 'right' way of incorporating imperfect competition, all alternative formulations are based on firms' profit maximisation behaviour subject to oligopolistic interaction and include estimations. Willenbockel (2004) and Rosen (2006) offer summaries of technical aspects of incorporating imperfect competition in CGE trade models.

${ }^{14}$ Data were obtained from the Kuwaiti Central Statistical Bureau and from the Kuwaiti Stock Exchange.
} 

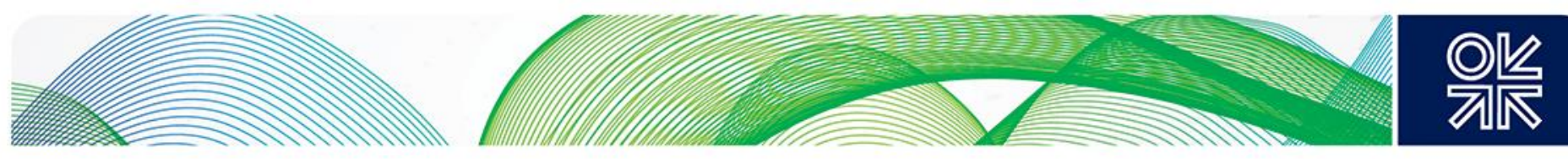

where $S_{i}^{j}$ denotes fully endogenous volume share of the home product in market $j$ for each source of demand $j$. These relationships are complex and Tyers (2014) details their analytics.

Importantly, these demand sources vary in elasticity, with export then final demand being the most elastic, while intermediate demand is the least elastic. Their values used to calibrate the demand side are initially drawn from the estimation literature. ${ }^{15}$

The aggregate household's expenditure function is used to derive the consumer price index (CPI), which is a Cobb-Douglas-CES index of after-tax prices of goods and services of both home products and imports. Collective utility is also defined as a Cobb-Douglas combination of consumption volumes by generic products, so the expenditure function in is Cobb-Douglas in prices and the CPI-deflated GNP is a measure of overall economic welfare.

\subsubsection{Supply side and oligopolies}

Production technology is Cobb-Douglas in variable factors and intermediate inputs, the latter being composites (CES nests) of home and imported products and services. The oligopolistic behaviour incorporates the pricing behaviour from Tyers (2014) which assumes that firms in a given industry $i$ supply a differentiated product and adopt profit-maximising pricing rules, with each carrying fixed capital and labour costs that capture unrealised economies of scale and lead to occurrence of pure (economic) profits (or losses) above market levels. Firms in $i$, therefore, face downward-sloping demand curves with elasticity $\varepsilon_{i}(<0)$ from the five demand sources, via (1). They set their price $p_{i}$ relative to average variable cost $v_{i}$ so as to maximise profit by applying the Lerner markup formula:

$m_{i}=\frac{p_{i}}{v_{i}}=\frac{1}{1+\frac{1}{\varepsilon_{i}}} \quad \forall i$.

All firms in all economic activities have oligopoly power in product and input markets. ${ }^{16}$ They also interact on prices, represented through calibrated conjectural variations. These parametrised values are critical because they capture the degree of price-setting collusion that occurs between the firms in a given industry. The values range between zero (non-collusive oligopoly) and unity (cartel). The conjectural variation parameters also the extent of existing regulatory surveillance; in the model, larger firms are subject to pricing surveillance regulation.

\section{Pure economic profits or losses:}

The model calculates pure or economic profits or losses by firms as revenue net of fixed and variable costs. Net economic profit in a given industry $\mathrm{i}$ is the post-tax profit after payment of $\tau_{i}^{K}$ net tax rate on capital income, as follows:

$\pi_{i}^{N}=\left[\left(p_{i}-v_{i}\right) Q_{i}-n_{i}\left(r f_{i}^{K}+w_{S_{K}} f_{i}^{S_{K}}+w_{S_{N}} f_{i}^{S_{N}}\right]\left(1-\tau_{i}^{K}\right) \quad \forall i\right.$.

where $n_{i}$ denotes is the number of firms in the industry; $r$ is the home real bond yield that captures the financing rate; $f_{i}^{K}$ is the fixed capital requirement per firm; $w_{S_{K}}$ and $w_{S_{N}}$ are wages for skilled Kuwait (subsubscript "K") and non-Kuwaiti labour (sub-subscript "N") in sector $i$, respectively; and $f_{i}^{S_{K}}$ and $f_{i}^{S_{N}}$ are the fixed skilled labour requirements per type per firm in industry $i$, respectively.

\subsubsection{Domestic prices}

Domestic prices are marked up over average costs. The unit variable cost is calculated as:

$v_{i}=b_{i} r^{\alpha_{i}} \prod_{k=1}^{k} w_{k}^{\beta_{k i}} \prod_{j=1}^{N}\left[\hat{P}_{j i}^{I}\right]^{\gamma_{j i}} \quad \forall i$,

where the scale coefficient $b_{i}$ and all the other listed exponents are calibrated from the SAM. Output elasticities are $\alpha_{i}$ for capital, $\beta_{k i}$ for factors $\mathrm{k}$. $\hat{P}_{j i}^{I}$ is a CES composite of home and imported input prices,

\footnotetext{
15 Summaries of this literature are offered by Dimaranan and McDougall (2002) and at http://www.gtap. purdue.edu/databases/.

${ }^{16}$ Firms do not have oligopsony power in the markets for purchased inputs or primary factors.
} 

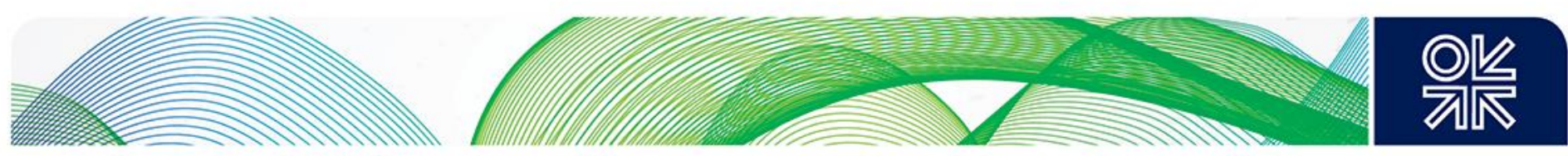

which are weighted by the shares of the domestic and import markets of the consuming industry $i$, as follows:

$\hat{P}_{j i}^{I}=\left[\phi_{j i}\left(p_{j}\right)^{\left(1-\sigma_{j}^{I}\right)}+\left(1-\phi_{j i}\right)\left(p_{j}^{*}\right)^{\left(1-\sigma_{j}^{I}\right)}\right]^{\frac{1}{\left(1-\sigma_{j}^{I}\right)}}$

where $\phi_{j i}$ is the domestic share of inputs from industry $j$ used by industry $i$. This relationship implies that domestic producer prices are simply higher by the markup, $m_{i}: p_{i}=m_{i} v_{i}, \forall i$.

\subsubsection{Factors of production and input demands}

The model has seven primary factors mentioned above. Solving the firm's cost minimisation problem with Cobb-Douglas technology in variable factors and inputs yields the volumes of each intermediate demand. Thus, the unit factor demands for capital $(K)$ and non-capital of $(L)$ are as follows:

$u_{i}^{K}=\frac{\alpha_{i} v_{i}}{r} \quad \forall i, \quad$ and $\quad u_{k i}^{L}=\frac{\beta_{k i} v_{i}}{w_{k}} \quad \forall k, i$,

Unit input demands are Leontief input-output coefficients, but they are not fixed in this model. Their values are determined by substitution behaviour in response to product and input prices. Therefore, the home product inputs and the imported inputs from industry $i$ used in the product of industry $j$ are, respectively, the following:

$A_{i j}=\gamma_{i j} \frac{\phi_{i j} v_{j}}{\hat{P}_{i j}^{I}}\left(\frac{p_{i}}{\hat{P}_{i j}^{I}}\right)^{-\sigma_{i}^{I}}, A_{i j}^{*}=\gamma_{i j} \frac{\left(1-\phi_{i j}\right) v_{j}}{\hat{P}_{i j}^{I}}\left(\frac{p_{i}^{*}}{\hat{P}_{i j}^{I}}\right)^{-\sigma_{i}^{I}} \quad \forall i, j$

\subsubsection{Government}

In the model, the government collects revenue from direct taxes on capital, labour income, land, resource rents, as well as from indirect taxes on trade and consumption expenditures. To account for government interventions at the firm level, corporate taxes are separated from subsidies and charged through industry specific rates. The government also makes direct transfers to the collective household, which can be set as exogenous in real terms and can be shocked, in which case one other fiscal variable must be made endogenous: the fiscal deficit, one of the tax rates, or government expenditure on goods and services. The government transfer variable is therefore exploited beyond the applications by Asano \& Tyers (2015). While in reality, Kuwait has limited taxation institutions, this representation facilitates the examination of trade-offs between welfare payments and between fiscal balance and cost of living stability following local or export price changes. It also enables the examination of possible fiscal policy changes in the future. While the fiscal deficit is endogenous, the government saving varies, driving the current account deficit. The household saving rate is fixed, and firms retain net earnings at corporate savings rates that are also fixed and industry specific. ${ }^{17}$ To represent capital movement, home assets are differentiated from foreign assets and also offer different yields, so that private finance flows across the border to follow departures from interest parity, being the difference between the home and foreign real bond yields and expectations of real exchange rate. Lastly, the real exchange rate is sensitive to the government's fiscal position because government expenditure is primarily on domestic, non-traded services.

\subsubsection{KIA}

Both KIA funds are represented as receiving payments from the government directly, rather than from the petroleum sector, but withdrawals are allowed in the form of government borrowing. The model represents funds as being available for withdrawal from abroad through KIA at a different rate, which represents the opportunity cost for withdrawing said funds for fiscal balancing. ${ }^{18}$

\footnotetext{
${ }^{17}$ Financial capital, whether domestically or foreign owned, can flow into the economy in the long run. There is no endogenous distinction between FDI as green-field investment or acquisition.

${ }^{18}$ While in reality the macro-stabilisation fund is the intended source for such withdrawals, the model does not distinguish between KIA funds, reflecting the lack of publicly available information about the composition and withdrawal practices of KIA.
} 

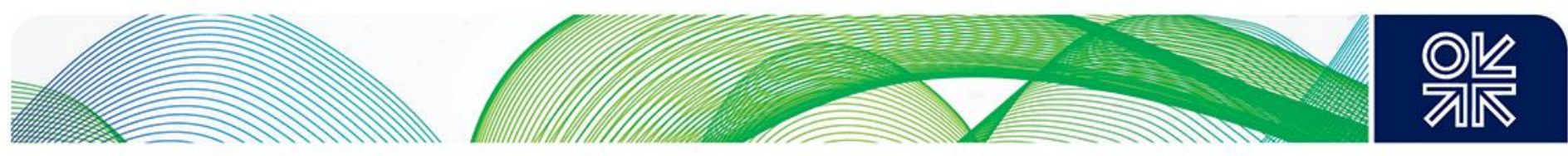

\subsection{Subsidies and Tax Representation}

In the standard model closure, tax revenue (or subsidy expense) and therefore the fiscal surplus or deficit, is endogenous, determined by the level of economic activity. The government raises tax revenue from both direct and indirect taxation, most rates applied being exogenous and constant (though some can be made endogenous, as needed), but the revenues earned depend on levels of economic activity. Further, artificial reductions in local prices below firms' output prices are captured as consumption subsidies to households. Consumption subsidies are applied at a uniform rate of $\tau_{i}^{C}<0$ on household final demand, approximated as the quotient of consumption subsidy expense provided to the household and their consumption value base. Thus, the total final consumption subsidy cost to the government is

$T_{C}=\sum_{i=1}^{N} \tau_{i}^{C} p_{i} D_{i}+\sum_{i=1}^{N} \tau_{i}^{C} p_{i}^{*} M_{i}$

where $D_{i}$ is the local final demand of home goods in industry $i$; $M_{i}$ is the local final demand of imported goods; $I_{i}$ is the industry input of home-produced goods; $I_{i}^{*}$ is the industry input of imported products; $p_{i}$ is the domestic price of home-produced goods; $p_{i}^{*}$ is the domestic price of imported goods; and $\tau_{i}^{C}$ is the ad valorem consumption tax rate for the products of industry $i^{19}$ Corporate subsidies (both reported and calculated on intermediate purchases) are accounted for against total taxes paid by each industry to arrive at a net corporate tax rate $\tau_{i}^{K}$. Initially, highly subsidised industries like electricity have a net large negative tax rate.

\subsection{Short Run Macroeconomic Behaviour}

The long-run version of the model is naturally Walrasian in that prices and interest rates all adjust to ensure that product, factor, and financial markets all clear. ${ }^{20}$ External flows are constrained by the balance of payments (which is implied by domestic agents, namely the household and the government, satisfying their budget constraints), which drives adjustments in the real exchange rate and the relative price of home goods in response to shocks. The model represents both foreign direct investments and official foreign reserve accumulation to complete the external financial accounts. ${ }^{21}$ The total capital stock of the economy is endogenous, as is the level of capital use in each industry. In the short run, however, capital is fixed at the industry level, so that rates of return change in response to shocks with values differing across industries. Further details on the long and short-run closures, including the implications for labour market behaviour, are offered below in the Closures subsection.

In both short and long-run versions of the model, the open economy capital market has a market clearing identity that accounts for inward and outward financial flows.

$I\left(r^{c e}, r\right)=S_{D}\left(Y_{D H}, \pi, G\right)+F I_{\text {Inward }}\left(r, r^{*}, \hat{e}_{R}^{e}\right)-F I_{\text {Outward }}\left(r, r^{*}, \hat{e}_{R}^{e}\right)$,

where $r^{c e}$ is the expected average net rate of return on installed capital; $r$ is the home bond yield (representing the real financing rate); $r^{*}$ is the foreign real post-tax yield on bonds abroad; $\pi$ is accounting profit; and $\hat{e}_{R}^{e}$ is the expected proportional change in the real exchange rate. Total domestic saving $S_{D}$ is the sum of saving by households $S_{H}$, corporations $S_{C}$, and government: $S_{D}=S_{H}\left(Y_{D H}\right)+S_{C}$ $(\pi)+(T-G)$. This total saving depends on the fixed domestic household savings rate $S_{H}$ applied to the home household disposable income $Y_{D H}$; the retained corporate earnings $S_{C}$; and the difference between the government tax revenue $T$ and total government expenditure $G$, on goods and services and transfers (direct subsidies are deductions from revenue). Notably, $S_{C}$ is assumed to remain a fixed

\footnotetext{
${ }^{19}$ This is a limitation in the current model. In future versions of the model, consumption subsidy will be differentiated through industry specific rates, which is critical for the adjustment of the overall price received for petroleum in the domestic market by the subsidies portion.

${ }^{20}$ Notwithstanding assumed rigidities in parts of the labour market, as these can be adjusted by closure changes in the model as described in Section 4.6.

${ }^{21}$ The capital, financial and official sub-accounts of the balance of payments are collectively referred to hereafter as the "capital account."
} 

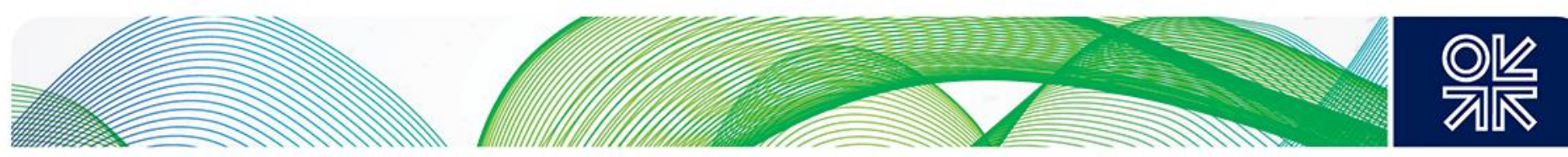

proportion of pre-tax accounting profit at rates that are industry specific, calibrated separately for each industry.

Pertaining to capital, the expected average net rate of return on installed capital $r_{i}^{c e}$ is the industryspecific expected average net rate of return on installed capital, calculated as follows:

$r_{i}^{c e}=\frac{P_{i}^{Y e} M P_{i}^{K}}{P^{K}}-\delta_{i}$,

where $P^{K}$ denotes the current price of capital goods; $P_{i}^{Y_{e}}$ is the price level of industry $i$ product expected to prevail upon gestation; $M P_{i}^{K}$ is the marginal productivity of capital in industry $i$; and $\delta$ is the depreciation rate. The economy-wide $r^{c e}$ is calculated through weighting each industry-specific rate by the value added in its respective industry. Therefore, the economy's investment expenditure, $l$, is determined a function of the initial level of investment $I_{0}$ as follows:

$I=P^{K} I_{0}\left(\frac{r^{c e}}{r}\right)^{\varepsilon_{V}}$.

In (11), $r^{c e}$ embodies the present value of assets; the denominator $r$ represents current financing costs. Thus, I responds to a change in either rate. This relationship offers a reduced form representation of either gestation costs or expectations over short-run consequences of installation for the rate of return.

Inward and outward financial flows follow changes in interest rate parity, which is the difference between the home and foreign real bond yields and expectations of real exchange rate. Two relationships are used in the model to allow for reversals of the direction of net flow as a response to shock and capital flows policy changes. Inward flows that have a negative elasticity $\varepsilon_{F O}$ and are divided between home and foreign portfolio decisions. They are represented by the following equation:

$$
F I_{\text {Inward }}=F I_{\text {lmward }}^{0}\left(\frac{\bar{r}^{c e} / \bar{\tau}_{K}+\hat{e}_{R}^{e}}{r^{*}}\right)^{\varepsilon_{F I}}, \quad \varepsilon_{F I}>0,
$$

where $F I_{\text {Inward }}^{0}$ is the initial inward inflow level; $\overline{r^{c e}}$ is the average $r^{c e}$ on home capital weighted across industries by gross revenue; and $\bar{\tau}_{K}$ is the average tax rate on capital income with similar weighting. In contrast, outward flows have a positive elasticity $\varepsilon_{F I}$ as they occur due to portfolio management decisions at home. This equation represents their form:

$$
F I_{\text {Outward }}=F I_{\text {Outuard }}^{0}\left(\frac{r / \bar{\tau}_{K}+\hat{e}_{R}^{e}}{r^{*}}\right)^{\varepsilon_{F O}}, \quad \varepsilon_{F O}<0,
$$

where the magnitude of the elasticity $\varepsilon_{F O}$ is larger for more liberal capital accounts. These flows are determined by the interest-or financing - rate, rather than the expected rate expressed in (10). Subsequently, the capital market clearing identity expressed in equation (9) determines the home real interest rate and the magnitude of the external financial deficit $\left(F I_{\text {Outward }}-F I_{\text {Inward }}=S_{D}-I\right)$. This value equals in magnitude to the current account surplus $(X-M+N$, where $N$ is net factor income from abroad $^{22}$.

\subsection{Capital in the Long Run}

In accordance with realistic changes in the long run capital use within an economy, and consistent with Kuwait's considerable external holdings, the model's long run closures allow changes through investment flows as represented in (12) and (13). This representation necessitates determining local

\footnotetext{
${ }^{22}$ As modeled, $N$ comprises a fixed net private inflow of income from assets abroad and fixed aid to the government, less
} endogenous repatriated earnings from foreign-owned physical capital. 

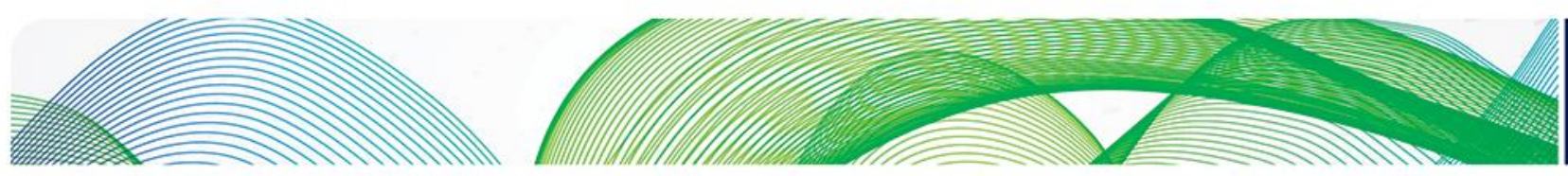

capital use $\left(K^{\top}\right)$ as well as the portion of it owned by Kuwait $\left(K^{D}=K^{\top}-K^{P}\right)$, calculated after subtracting foreign-owned capital from $K^{\top}$. Total capital use in the economy does not change with changes in $K_{D}$, unlike repatriated capital income levels which impact the real exchange rate and GNP. Capital flows are set at the level where post-tax rates of return at home equal rates internationally, while also allowing firms to generate rents consistent with oligopoly behaviour. Therefore, capital use level equates posttax capital rate of return to post-tax "market" returns, net of pure profits.

$$
\frac{R_{i} / \tau_{i}^{K}}{P_{K}}-\delta=r^{*},
$$

where the home capital rental rate is $R_{i}=P_{i}^{P} M P_{i}^{K}$ as per (11), where $M P^{K}$ is a function of total capital use, and $\tau_{i}^{K}$ is the power of the industry-specific capital income tax (net of subsidy) rate. Accordingly, cuts in taxation rates of capital income (or conversely, increases in subsidies) will cause the pre-tax rate of return demanded at home to drop and capital use to, correspondingly, increase. The long-run response of the home-owned share of this capital is the following:

$$
K_{D}=K_{D}^{0}\left(\frac{R G N P}{R G N P_{0}}\right)^{\varepsilon_{K D Y}}\left(\frac{K^{T}}{K_{0}^{T}}\right)^{\varepsilon_{K D T}}, 1>\varepsilon_{K D Y}, \varepsilon_{K D Y}>0 .
$$

Important to the analysis, changes in real income levels at home impact long-run accumulations of home-owned capital.

\subsection{Closures}

Closures represent assumptions as to which variables are free to change in response to shocks and which variables can adjust. They reflect policy targets and market clearance assumptions. While comparative static, the model employs two generic closures to represent the responses of the Kuwaiti economy in the short and the long runs. As such, the closure adopted in each simulation drive the differences between the model's short and long-run results. These closures have four sub-closures reflecting four elements, as follows.

First, labour market closures distinguish between the effects of shocks that either yield changes in real wages combined with full-employment or hold real wages fixed with changes in employment.

Second, fiscal closures determine the elements of government revenue or expenditure that are held constant and the ones that adjust.

The third is the financial capital market closure, which determines whether capital use adjusts with exogenous required rates of return or is fixed at the industry level.

And fourth, there is a market structure (oligopoly) sub-closure that either requires a fixed number of firms and endogenous profitability or allows firms entry and exit to adjust to sustain constant profitability as per Chamberlinian monopolistic competition.

In this application to Kuwait, expatriate employment of both skilled and unskilled labour is endogenous in both lengths of run, while Kuwaiti employment is fixed in both. The real expatriate skilled and unskilled production wage rates (relative to an index of producer prices) are held fixed, while the real Kuwaiti skilled and unskilled production wages are endogenous. This closure is set this way, first, to represent the inflexibility of the majority of Kuwaiti workers, who are likely to remain employed in the public sector, yet are sectorally mobile. Second, it accounts for the long-run flexibility of expatriate worker contracts, given that the stock of expatriate workers can fall with a decline in labour demand in both the short and long runs.

The capital market closures are discussed above. In the short run, physical capital use is fixed at the industry level with endogenous rates of return; in the long run, the capital stock of the entire economy 

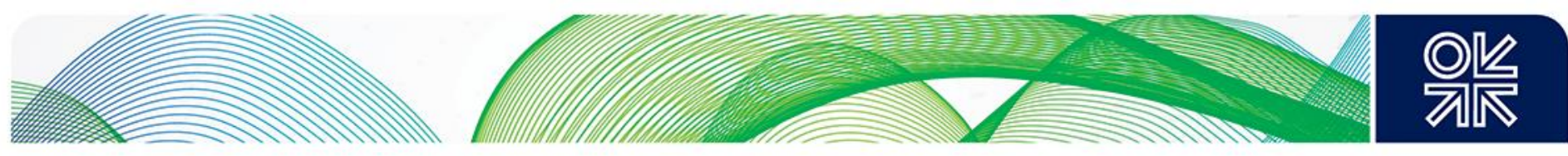

is mobile so it adjusts (rises or falls) to maintain a fixed rate of return in all industries, with implications for financial flows on the balance of payments. ${ }^{23}$

In the short-run, the default fiscal closure is to retain the governmental surplus as constant, allowing expenditures on goods and services and consumption subsidies to adjust to maintain fiscal balance. Variations on this setting allow the fiscal balance to become endogenous, to represent more realistically the changes in either the fiscal deficit and/or transfer payments that result from the fall in petroleum export revenue. Finally, the oligopoly sub-closure retains constant firm numbers and endogenous profitability in the short run. This setting is occasionally reversed in long-run applications.

\section{Analysis of Shocks and Reforms}

The paper undertakes four types of analysis, each examined in both the short and long runs. The first concerns the drop in the oil price without change in any policy instruments. The second combines the first shock with only a small increase in local energy prices, reflecting the kind of policy promoted by some members of parliament (and of policy which is potentially politically acceptable). The third combines this shock with implementation of the kind of energy pricing reform intended by the Kuwaiti government (similar to that implemented in August 2016 and opposed by the parliament), whereby local energy prices are raised to match the international shadow price. The final investigation concerns a hypothetical microeconomic policy reform (that includes competition policy and productivity boosts), which is implemented to assuage negative impacts of subsidy reform in a persistent low petroleum price environment.

\subsection{Drop in Export Petroleum Price}

To illustrate the impact of drops in petroleum export revenue in Kuwait, the export petroleum price is decreased by $5 \%$. This scenario maintains the assumption that welfare distribution and public employment policies remain in effect and that the fiscal surplus remains fixed. As such, both the short and long-run simulations adopt the same closures for labour and fiscal variables. Both closures have fixed Kuwaiti labour employment and flexible expatriate employment. The adopted fiscal closure is exogenous fiscal deficit and welfare payments with endogenous government spending on goods and services and an endogenous consumption subsidy rate. For the capital market closure element, in the short run, productive capital use in each industry is fixed with varying rates of return, while in the long run, capital is sectorally and internationally mobile at fixed rates of return. The short run market structure sub-closure has fixed firms and endogenous profitability, while in the long run adopts a Chamberlinian oligopoly closure that allows free entry and exists of firms to sustain exogenous pure profits. The real exchange rate is endogenous. Importantly, the model cannot find solutions when the petroleum price is reduced beyond $5 \%$ while all economic policies remain in effect, suggesting the unviability of the current economic policies at persistently low petroleum prices-a statement that echoes official assessments of the country's economic future. Although a $5 \%$ drop appears small, its effect on the economy under these circumstances is substantial. Table 5 summarises the results. This shock contracts all economic activity. In the short run, the macroeconomic and welfare impacts include losses in real GNP and real GDP and a depreciation in the real exchange rate. These changes are magnified in the long run.

\footnotetext{
${ }^{23}$ The total stock of physical capital varies in the long run and the home-owned share of it depends, as discussed earlier, on corresponding long run changes in domestic real income and on the share of wealth held abroad. The home-owned share of domestic capital is important because it affects the level of factor income outflow associated with profit repatriation.
} 

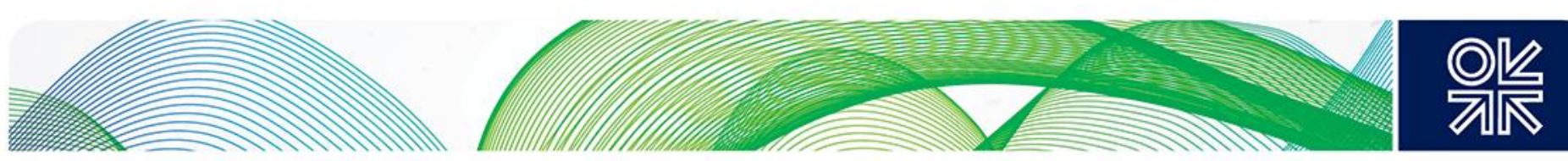

Table 5: Impact of oil export price decline, holding fiscal balance and welfare policies fixed

\begin{tabular}{|c|c|c|}
\hline \multirow[t]{2}{*}{ Variable } & \multicolumn{2}{|c|}{$\begin{array}{c}\text { Percentage change (departure from } \\
\text { baseline) from a } 5 \% \text { decline in oil export } \\
\text { revenue }\end{array}$} \\
\hline & Short run & Long run \\
\hline \multicolumn{3}{|l|}{ Macroeconomic and output indicators } \\
\hline Real GDP & -0.05 & -9.63 \\
\hline Real GNP & -3.04 & -12.48 \\
\hline Real exchange rate & -4.24 & -3.90 \\
\hline Real rate of return on capital, gross of tax & -3.51 & -4.78 \\
\hline Capital stock & 0.00 & -7.69 \\
\hline Non-petroleum exports/GDP & 2.61 & 3.02 \\
\hline Investment expenditure/GDP & -10.2 & 1.59 \\
\hline \multicolumn{3}{|l|}{ Government } \\
\hline Government expenditures on goods and services & -3.78 & -32.77 \\
\hline Current account/GDP & 8.89 & -4.30 \\
\hline Government expenditure/GDP & -0.67 & -5.86 \\
\hline $\begin{array}{l}\text { Required change in consumption subsidies } \\
\text { (households) }\end{array}$ & 3.27 & 3.37 \\
\hline \multicolumn{3}{|l|}{ Labour market } \\
\hline Unskilled expatriate labour & -1.09 & -10.63 \\
\hline Skilled expatriate labour & -1.02 & -11.91 \\
\hline \multicolumn{3}{|l|}{ Welfare } \\
\hline Real disposable income, CPI deflated & -2.67 & -9.01 \\
\hline \multicolumn{3}{|l|}{ Pricing and costs } \\
\hline Average markup & -0.91 & 1.84 \\
\hline Fixed costs/GDP & -0.44 & -1.69 \\
\hline Pre-tax pure profits/GDP & -0.68 & 0.56 \\
\hline
\end{tabular}

Source: Simulation results.

The results reveal important insights on the mechanisms by which the government could finance its rigid current expenditures, including the large public wage bill and welfare payments. To maintain fiscal balance, government expenditures on goods and services would have to drop by $4 \%$, which contributes to the decline in GDP. An increase in non-petroleum government revenue is also required. As corporate and income tax rates remain fixed, a 3.3\% decrease in household consumption subsidies would be required to maintain the initial fiscal position. In practice, this decrease could be achieved through increasing energy prices, given that $10 \%$ of households' final consumption is on energy products.

There is an increase in industries' costs that is offset by a depreciation in the real exchange rate, ${ }^{24}$ which is itself the result of the decrease in petroleum export revenues and the decline in investment expenditure driven by the lower rate of return on capital in the short and long runs. The depreciation renders imported final and intermediate inputs relatively more expensive. As local energy prices are artificially set lower than the international oil price, the drop in the latter does not, in this simulation, translate to a reduction in local final costs or local industries' intermediate energy costs. A drop in consumption subsidies, as would be required to maintain a fixed fiscal deficit, would be akin to an increase in tax and, therefore, costs, maintaining the wide gap between the consumer price and the producer price. Households' welfare, measured by real disposable income deflated by the CPI, drops by $2.7 \%$ in the short run and a substantial $9 \%$ in the long run.

\footnotetext{
${ }^{24}$ The nominal exchange rate is exogenous, so does not devalue in this scenario, consistent with Kuwait's nominal exchange rate that is pegged to a basket of currencies.
} 

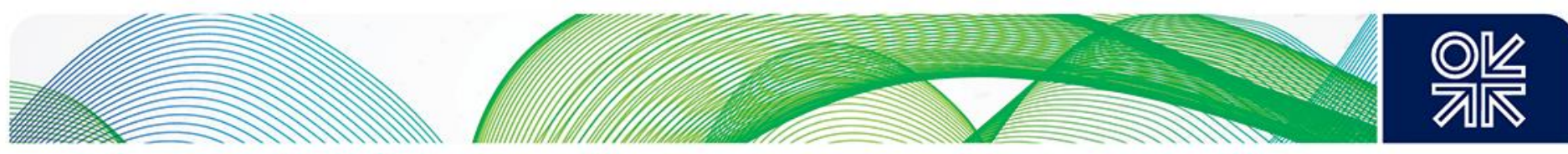

Two primary stabilisation valves that partially absorb the negative impacts of oil price shocks are revealed. The first, obvious, channel is inflows from the SWF, which is typically shown as a large financial inflow to the government, allowing it to finance its fiscal commitments and maintain its fiscal position, thus stabilising the economy.

The second stabilisation mechanism is expatriate labour exit. The dynamics of the labour market entails different impacts of this contractionary shock on the two labour segments. Typically, as the real wages of expatriate workers are assumed to be sticky (in both the short and long run), employment levels adjust instead. Since most Kuwaitis are employed by the public sector, where contracts are rigid, their employment is unaffected. By contrast, the flexibility of expatriate labour contracts allows affected industries to adjust their employment levels, causing a similar decline in employment levels of skilled and unskilled expatriates. The reallocation of resources following the drop in petroleum prices could, theoretically, provide additional employment opportunities in the expanding non-oil industries for the recently unemployed. In practice, however, such opportunities are limited in the short run, especially for expatriates, depending on changes in demand facing private non-oil firms and their ability to expand in the long run.

The resulting unemployment is unlike traditional unemployment in that the unemployed expatriates cannot remain in Kuwait until the advent of new expansion because their temporary residency is employer-dependent. Without employment sponsorship, they must exit (with some having mobility opportunities across the GCC states). As expatriates' wages are generally lower than those of Kuwaitis, their exit contributes to the above-described adjustments on the production side, and to potentially smaller adjustments on the consumption side. Nonetheless, in a mechanism unique to GCC states with this kind of labour market, exiting by expatriates' acts as a cushion, absorbing the shock.

Industry-wise, the performance of non-oil exporting sectors (Chemicals, Light and Heavy Manufacturing, Other Network Services, and Transportation) is boosted, owing to factor movements to them away from the contracting petroleum sector, coupled with increased competitiveness of their exports caused by the depreciating real exchange rate. Fixed capital use in the short run leads to gains by the comparatively labour-intensive production of transportation and manufacturing, with the effects differing depending on labour market structures and international labour mobility. In the long run, the mobility of capital away from petroleum and non-tradable sectors to these expanding ones enables further expansions in non-resource exporting industries (Corden, 2012). This expansion, known as reverse Dutch Disease effect, ${ }^{25}$ moderates the net effect on the economy of contraction in resourceintensive activity. Nonetheless, the potential impact of the stated effects depends on the magnitude of the real depreciation, the level of factor mobility, and the scale of revivals in other tradable industries. In reality, the movement of capital away from the Kuwaiti petroleum industry is potentially restricted. As such, the simulation results suggest that reverse Dutch Disease moderation is limited in Kuwait in the current economic conditions and industrial structures. The expanding industries' contributions to value added in the economy do not change significantly from the initial equilibrium levels. Their contributions to export revenue rise as their output increases, but only marginally. Thus, this expansion is insufficient to cause compensatory structural change.

The effects on efficiency are minimal. Production scale in both tradable and non-tradable products is not affected. Markups decrease for all industries in the short run, though some industries manage to recover these markups in the long run as they expand. Oligopoly rents only negligibly decrease in the short and long runs and, consequently, pricing does not become more competitive. Although largely unchanged from the base scenario, markups and pure profit for the larger industries remain especially high, implying the oligopolistic firms' markups are significant and that a large part of the economy's inefficiency is captured (and reduced) by distortionary oligopoly rents. The pervasiveness of subsidies

\footnotetext{
${ }^{25}$ Dutch Disease refers to instances when a boom in the exports of natural resources leads to a significant appreciation of nominal (and real) exchange rates (or inflation in countries with fixed exchange rates regimes), which in turn adversely affect the non-resources tradable sectors and cause a boom in nontraded services sectors (Corden, 1984, 2012; Corden \& Neary, 1982; Venables \& van der Pleog, 2010).
} 

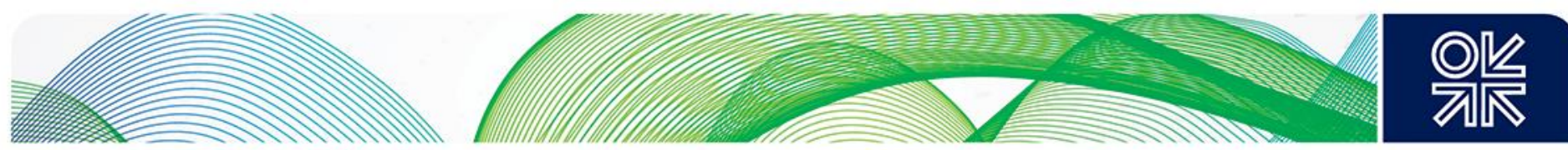

keeps consumer prices artificially low, while allowing producers to sustain high mark-ups. Overall, the results of this simulation suggest the substantial implications for Kuwait of export price declines under existing policy regimes, and indicate scope for substantial reforms to energy pricing and fiscal policy that would raise aggregate welfare under these circumstances.

\subsection{Oil Price Drop Combined with Subsidy Reform Allowing Adjustments in Fiscal Deficit and Welfare Payments}

To quantify the impact of the Kuwaiti government's plans to reduce energy subsidies but in a potentially politically palatable way, the model is simulated with the previous negative shock to petroleum exports combined with an equal percentage decrease in energy subsidy, which effectively increases the domestic price of crude and refined petroleum products paid by households and industries. While in effect this is a marginal increase in domestic energy price, it is of the magnitude promoted by some parliamentary members who accept the necessity of reducing subsidies but oppose large price hikes. Therefore, to implement the shock, the single household consumption subsidy rate is reduced by $0.5 \%$, pro-rated based on the share of households' energy consumption in overall final demand. The corporate subsidy rate (and therefore the net corporate tax rate) is reduced also by $0.5 \%$ for all nonpetroleum industries, calculated on a pro-rated basis. This scenario relaxes the fixed fiscal deficit and fixed welfare payment assumptions to reflect realistic adjustments in the economy. To that end, the adopted fiscal closure is different from that used in the first simulation by having endogenous fiscal deficit and welfare payments with exogenous government spending on goods and services and exogenous consumption subsidy rate and corporate tax rates (both of which are shocked). The closures chosen for the remaining three elements are the same as those in the previous simulation. Table 6- column (a) summarises the results.

Notably, the results indicate that the reduction of energy subsidies assuages many of the negative macroeconomic impacts of the petroleum price shock on the economy, simulated through a $5 \%$ drop in the petroleum export price. Real GNP drops by half of the value caused by the petroleum price shock, while real GDP decreases by more than the original drop, driven by a larger loss in investment. Government expenditures on goods and services is assumed to remain exogenously constant. Yet welfare payments to Kuwaiti citizens endogenously adjust downwards in response to the shocks, which is contrary to the government's historical practices of compensatory payments. Nevertheless, households adjust their consumption behaviour of energy products, but only slightly as the conservative drop in energy prices is insufficient to cause a shift in the elasticity of final demand for local energy products. 


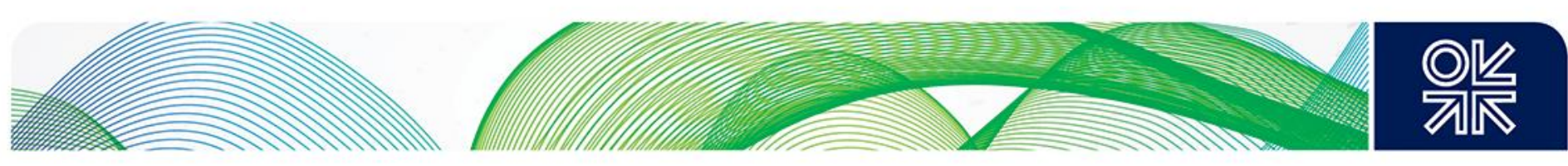

Table 6: Impact of reform shocks combined with petroleum price declines on selected economic variables

\begin{tabular}{|c|c|c|c|}
\hline \multirow[b]{2}{*}{ Variable } & \multicolumn{3}{|c|}{$\begin{array}{l}\text { Percentage change (departure from baseline) from a } 5 \% \\
\text { decline in petroleum prices combined with reform }\end{array}$} \\
\hline & $\begin{array}{c}\text { (a) } \\
\text { Subsidy } \\
\text { decrease: } \\
\text { households } \\
\text { and } \\
\text { Firms }-0.5 \% \\
\end{array}$ & $\begin{array}{c}\text { (b) } \\
\text { Subsidy } \\
\text { reform: } \\
\text { Household - } \\
5 \% ; \\
\text { Firms }-3.5 \% \\
\end{array}$ & \begin{tabular}{|c|} 
(c) \\
Subsidy reform; \\
Conjectural variation - \\
$20 \%$; productivity $2 \%$ SR/ \\
$5 \%$ LR
\end{tabular} \\
\hline \multicolumn{4}{|l|}{ Short run } \\
\hline Real GDP & -0.23 & 0.66 & 18.77 \\
\hline Real GNP & -1.50 & -3.44 & 23.38 \\
\hline Real exchange rate & -3.72 & -4.27 & -9.14 \\
\hline $\begin{array}{l}\text { Real rate of return on capital, gross } \\
\text { of tax }\end{array}$ & -2.79 & -3.52 & 8.55 \\
\hline Capital stock & 0.00 & 0.00 & 0.00 \\
\hline $\begin{array}{l}\text { Unskilled expatriate labour } \\
\text { employment }\end{array}$ & 1.83 & -0.54 & 41.84 \\
\hline Skilled expatriate labour employment & 1.89 & -0.44 & 35.47 \\
\hline Fiscal deficit/GDP & -2.05 & 0.36 & -0.47 \\
\hline Welfare payments & -1.96 & 1.69 & -13.79 \\
\hline Current account/GDP & 5.00 & 10.26 & -11.75 \\
\hline Investment expenditure/GDP & -7.76 & -11.29 & 15.73 \\
\hline Household energy consumption & 2.57 & -2.09 & 0.00 \\
\hline Non- petroleum exports/GDP & 1.92 & 2.77 & 13.09 \\
\hline Real disposable income, CPI deflated & 0.80 & -3.76 & 30.19 \\
\hline $\begin{array}{l}\text { Real Kuwaiti unskilled wage, PC } \\
\text { deflated }\end{array}$ & -0.10 & -0.66 & 5.49 \\
\hline $\begin{array}{l}\text { Real Kuwaiti skilled wage, PC } \\
\text { deflated }\end{array}$ & 0.01 & -0.54 & 3.36 \\
\hline $\begin{array}{l}\text { Real expatriate unskilled wage, PC } \\
\text { deflated }\end{array}$ & -0.20 & -0.61 & 0.45 \\
\hline $\begin{array}{l}\text { Real expatriate skilled wage, PC } \\
\text { deflated }\end{array}$ & -0.20 & -0.61 & 0.45 \\
\hline Pre-tax pure profits/GDP & -0.38 & -0.79 & -3.02 \\
\hline Average markup & -0.007 & -0.013 & -0.20 \\
\hline Average markup, non-oil tradables & -0.83 & -1.29 & -5.30 \\
\hline $\begin{array}{l}\text { Average markup, nontradable } \\
\text { services }\end{array}$ & -0.55 & -1.23 & -30.25 \\
\hline Fixed costs/GDP & -0.24 & -0.46 & 3.18 \\
\hline \multicolumn{4}{|l|}{ Long run } \\
\hline Real GDP & & -9.68 & 1.64 \\
\hline Real GNP & & -14.41 & -2.92 \\
\hline Real exchange rate & & -2.71 & -5.08 \\
\hline $\begin{array}{l}\text { Real rate of return on capital, gross } \\
\text { of tax }\end{array}$ & & -6.05 & -0.24 \\
\hline Capital stock & & -9.11 & -4.57 \\
\hline $\begin{array}{l}\text { Unskilled expatriate labour } \\
\text { employment }\end{array}$ & & -0.05 & 13.45 \\
\hline Skilled expatriate labour employment & & -0.04 & 10.74 \\
\hline Fiscal deficit/GDP & & -8.53 & -5.34 \\
\hline Welfare payments & & 3.34 & -1.34 \\
\hline
\end{tabular}



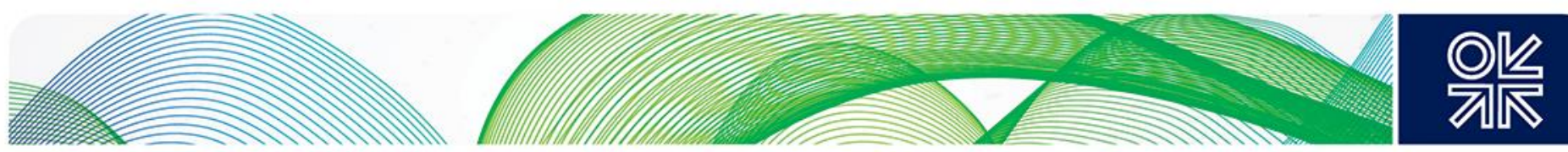

\begin{tabular}{|c|c|c|c|}
\hline \multirow[b]{2}{*}{ Variable } & \multicolumn{3}{|c|}{$\begin{array}{l}\text { Percentage change (departure from baseline) from a } 5 \% \\
\text { decline in petroleum prices combined with reform }\end{array}$} \\
\hline & $\begin{array}{c}\text { (a) } \\
\text { Subsidy } \\
\text { decrease: } \\
\text { households } \\
\text { and } \\
\text { Firms }-0.5 \%\end{array}$ & $\begin{array}{c}\text { (b) } \\
\text { Subsidy } \\
\text { reform: } \\
\text { Household - } \\
5 \% ; \\
\text { Firms }-3.5 \%\end{array}$ & $\begin{array}{c}\text { (c) } \\
\text { Subsidy reform; } \\
\text { Conjectural variation - } \\
20 \% \text {; productivity } 2 \% \text { SR/ } \\
5 \% \text { LR }\end{array}$ \\
\hline Current account/GDP & & -12.83 & -5.88 \\
\hline Investment expenditure/GDP & & 3.21 & 1.32 \\
\hline Household energy consumption & & -5.14 & 3.97 \\
\hline Non-petroleum exports/GDP & & 1.75 & 7.73 \\
\hline Real disposable income, CPI deflated & & -5.40 & 4.55 \\
\hline $\begin{array}{l}\text { Real Kuwaiti unskilled wage, PC } \\
\text { deflated }\end{array}$ & & -11.5 & 9.8 \\
\hline $\begin{array}{l}\text { Real Kuwaiti skilled wage, PC } \\
\text { deflated }\end{array}$ & & -10.8 & 2.4 \\
\hline $\begin{array}{l}\text { Real expatriate unskilled wage, PC } \\
\text { deflated }\end{array}$ & & -6.0 & -4.0 \\
\hline $\begin{array}{l}\text { Real expatriate skilled wage, PC } \\
\text { deflated }\end{array}$ & & -6.0 & -4.0 \\
\hline Pre-tax pure profits/GDP & & 1.41 & -5.25 \\
\hline Average markup & & 0.67 & -1.78 \\
\hline Average markup, non-oil tradables & & -0.95 & -2.36 \\
\hline $\begin{array}{l}\text { Average markup, nontradable } \\
\text { services }\end{array}$ & & 1.39 & -2.37 \\
\hline Fixed costs/GDP & & -0.37 & 0.22 \\
\hline
\end{tabular}

Source: Simulation results.

The depreciation in the real exchange rate is $3.72 \%$, which is smaller than under scenario 1 . As such, prices of imported intermediate inputs increase from the base level, but become more affordable than under scenario 1. Although local prices for industries increase with the small increase in local energy prices, import-competing industries are able to expand due to the increased competitiveness for their exports, unfettered demand by Kuwaiti households, and increased government borrowing that sees increased inflows on the capital account that sustain demand. Accordingly, these industries increase their output and employment. Additional labour demand is met by hiring additional expatriate workers, who are mobile with flexible employment contracts. The wages of Kuwaiti workers and, consequently, their welfare also increases. Overall welfare for all consumers increases in the short run and more so in the long run. Thus, the relatively low drop in subsidies could be politically palatable.

Nevertheless, this drop fails to achieve the required fiscal sustainability, which was the goal of the energy price increases (by reducing subsidy) in the first place. Withdrawals from KIA continue to be large in the short run and even larger in the long run. Further, the loss of petroleum revenues exceeds the additional government savings brought about by reducing subsidies, resulting in a very large fiscal deficit in the short and long runs. In addition, the price increases are not seen to curb energy demand in the long run, as hoped for by the government.

As to economic efficiency, there is a decrease in oligopolies' pure profits as a percentage of GDP, indicating an increase in the economy's overall competitiveness. A key mechanism through which oligopoly rents affect growth performance is by reducing the cost of intermediate services during economic contractions, depreciating the real exchange rate, and contributing to raising the economy's overall competitiveness. Here, the relative increase in the tradable input costs owing to the depreciating exchange rate coupled with the increase in locally-sourced input costs cause oligopolistic firms' average costs curves to shift upwards. Consequently, average markups decline for all industries. Specifically, 

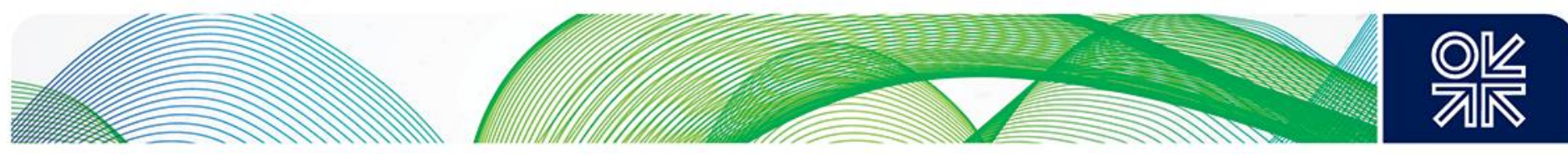

average markups for non-petroleum tradables fall not only because of this increase in input costs, but also as their competitiveness rises due to the real exchange rate depreciation rendering their exports relatively more affordable in the international market. Consequently, the share of exports (the most elastic demand source) of home output increases, causing reduced markups and leading to lower oligopoly rents. This drop coupled with the increase in scale both contribute to a higher efficiency in the economy. This result is consistent with observations by Menezes (2009) even if price-cap regulation is imposed. Lower rents, in turn, increase economic efficiency, competitiveness, and growth, albeit marginally, thus moderating the overall downturn's impact on the economy. This mechanism confirms the argument advanced in this paper that, through their decline, substantial oligopoly rents play an important role in stabilising the Kuwaiti economy during busts.

Based on the results, it may reasonably be expected that this scenario is acceptable to the parliament - slight cuts in welfare payments are mitigated by overall gains in household welfare and industry performance. Nonetheless, non-petroleum output expansion and short-run gains are all dwarfed by larger declines in petroleum (crude and refined) output in the long run. By not generating sufficient fiscal adjustments in government finances, the examined drop in subsidies does not provide a solution to the budgetary problems; hence the examination of larger subsidy cuts in the next scenario.

\subsection{Subsidy Reform}

This analysis quantifies the impact of energy pricing reform in current economic conditions of the type intended by the Kuwaiti government whereby local energy prices are raised to match the international shadow price. Thus, this scenario simulates the effects of a $5 \%$ drop in the petroleum export price combined with a $5 \%$ decrease in households' consumption subsidy rate and a $3.5 \%$ decrease in the corporate subsidy rate (showing effectively as an increase of $3.5 \%$ in the net corporate tax rate) of nonpetroleum industries. The shocks on subsidy and tax rates are calculated based on a pro-rata basis to reflect a $40 \%$ increase in domestic energy prices. This scenario adopts the same closures as the previous scenario, and allows the fiscal deficit and welfare payments to adjust, while holding the government's expenditures on goods and services constant. Table 6- column (b) summarises the results.

Overall, the results indicate that the examined fiscal adjustments achieve the government's overall fiscal sustainability goals in the short term. Fiscal improvements are largely driven by large savings obtained through a reduction in the cost of subsidy payments to both households and industries. The government increases welfare payments marginally, partially offsetting the effects of price hikes on households. The resumption of investing savings abroad in the KIA is then possible, improving the country's net asset position abroad in the short run. Other macroeconomic effects include a slight increase in real GDP and a depreciating real exchange rate as above similar in magnitude as seen in scenario 1. Overall, this is a negative shock evidenced by a drop in the aggregate welfare measure real GNP, also similar in magnitude as under scenario 1.

Both final consumers and industries suffer losses. Household final consumption declines, driven by the fall in real disposable income (while savings remain constant). Real disposable income is affected by an increase in CPI due to increases in real prices of locally-produced goods (owing to the removal of energy subsidies) and to the relative increase in imports' prices owing to the depreciating real exchange rate. These effects yield a $3.67 \%$ loss in household welfare, measured in terms of real disposable income deflated by CPI. Input costs for industries also increase, limiting the potential expansion of nonpetroleum exporting industries. As such, firms are forced to cut costs, and the cost of hiring will be particularly high especially for industries that use energy as an intermediate input. Any adjustments in public sector employment impacts expatriates only due to the flexibility of their employment contracts. By contrast, Kuwaiti labour employment and real wages are not impacted. The private sector suffers employment cuts across all employees, but given that $95 \%$ of the sector's employees are non-Kuwaiti, layoffs are largely among expatriates, affecting unskilled more than skilled expatriate labour. Consequently, expatriates' real incomes drop, and their unemployment leads to their exit from the labour market in Kuwait. 

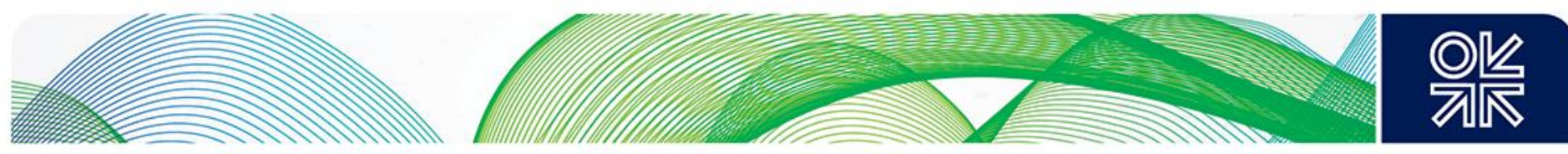

Improvements in efficiency, however, partially compensate for the output losses of the effected industries. With the relative increase in imported intermediates' costs and the large increase in local energy costs, exporting non-petroleum industries are directed away from the least elastic intermediate and investment demand to the more elastic export and final demand. Consequently, their markups decline. The oligopolistic non-tradable industries, particularly Construction and Network Services, are largely consumed locally as domestic intermediates rather than as exports. Accordingly, reductions in their markups will have substantial indirect effects that accumulate economy-wide. Conversely, they will have only modest direct effects (on final product markups). Average markup changes by the affected industries are larger than those by the expanding (exporting) industries. Reductions in markups entail increasingly competitive pricing, generating an overall positive effect on economic activity and raising real GDP. Scale efficiency also expands for the expanding industries, further enlarging the reverse Dutch Disease effects caused by the contracting petroleum industry.

In the long run, however, assuming a continually low oil price, the fiscal improvement is unsustainable: the government fiscal deficit substantially worsens, necessitating large withdrawals of KIA funds to finance government expenditures. The real exchange rate further depreciates, real GNP and real GDP deteriorate, and welfare losses intensify. The non-petroleum exporting industries become more competitive owing to the depreciating exchange rate, and they benefit from the movement of labour and capital away from the negatively impacted industries and increase their output. It turn, these dynamics cause additional deindustrialisation in the negatively impacted industries. Capital flows out of the economy given declines in returns locally, which further hurts non-petroleum production. Industries will thus demand more labour to meet output requirements, requiring expatriates to re-enter the economy. The overall employment level of expatriates is very similar to that in the initial equilibrium, a result that has critical implications for the labour market and its dependence on international labour mobility. Crucially, much of the short run efficiency gains are lost, with only minimal improvement in competitiveness from the initial base level.

In conclusion, the short-run results of fiscal gains, economic expansion, and improvements in economic efficiency and competitiveness suggest that subsidy reform of the kind examined in this scenario will be favoured by the government. Indeed, these results in the short run seem in line with some of the government's promises in September 2016. Nonetheless, the long-term impacts of these reforms are critical: not only does reform not achieve the government's goals of fiscal sustainability, it worsens welfare and competitiveness gains. It will also be costly for firms as they will have to source expatriate workers from abroad, given expatriate labour exit in the short run. This analysis confirms the unsustainability of the economy in a low oil price environment absent changes in its economic, labour, and oligopolistic structures. The substantial scope for fiscal adjustments and competition reform in Kuwait motivates the final analysis, which explores the possible effects of subsidy reforms combined with other reforms.

\subsection{Competition Reform}

The pervasiveness of oligopolies that sustain large markups and their collusive pricing in the economy both suggest that there is considerable scope for competition reform in Kuwait. This is further confirmed by Kuwait's various Five-Year Development Plans, which have the explicit goal of expanding the private sector coupled with increasing competition within the overall economy. To illustrate possible policy solutions that could be implemented in combination with energy pricing reform in a low petroleum price environment, two hypothetical competition policy reforms are introduced simultaneously: tighter pricing surveillance that reduces collusive behaviour across all non-petroleum industries, simulated through a $20 \%$ reduction in the tendency for businesses to collude on prices (represented by the conjectural variations parameters); and improvements in private and services sectors' productivity of $2 \%$ in the short run and $5 \%$ in the long run. These sectors are non-tradable Construction and Other Services, and tradable Chemicals and Transport industries. Tables 6- column (c) summarises the results.

Competition reform can yield substantial improvements in performance. In industries where large initial markups exist, like the Construction industry, which also uses energy as an input, more competitive 

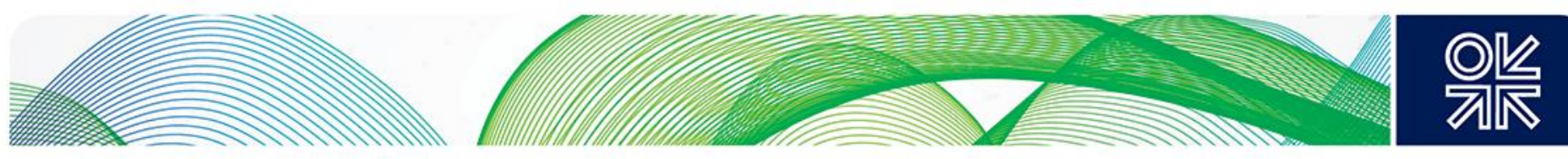

pricing generates significant drops in markup. These drops yield effects on overall economic activity that largely exceed the neoclassical gains in allocative efficiency from removing price distortions due to taxes, subsidies, and regulation. Unsurprisingly, the result is expansionary for the overall economy in the short run, achieving very large gains at the macro and microeconomic levels. Fiscal improvements are substantial, similar to those achieved during high petroleum price episodes, enabling the resumption of large investments in KIA and asset accumulation abroad. The overall expansion in the economy coupled with the substantial increase in disposable income reduces the need for large welfare payments, enabling the government to make additional budgetary savings and reducing citizens' reliance on the government. Particularly, limiting collusion slashes the large pure profits captured by oligopolies, offering gains distributed across the economy as a whole. The ensuing increased competition generates efficiency gains that are augmented by further gains stemming from the increase in productivity of the private sector and services. The gains further reduce markups and increase production scale.

The real exchange rate depreciates substantially, by approximately double the depreciation in the previous simulations in both the short and long runs. As in the previous scenarios, the depreciation is driven by the fall in petroleum exports while the decline in investments is driven by the lower rate of return on capital. Moreover, in this scenario the increase in efficiency allows firms to increase production scale gains and reduce overall costs, further depreciating the exchange rate. This depreciation renders imported intermediates and final goods more expensive, but increases the competitiveness of all non-oil exports, enabling their expansion. With capital fixed in the short run, the expanding industries demand more labour to meet their increased output, which can be met by additional expatriate labour. The increase in disposable income (and the welfare measure) encourages higher consumption of locally-produced goods, which is met with additional local output in all industries in the short run. The increased disposable income and industry expansion also leads to increased demand of imported goods, further depreciating the exchange rate. Unlike all previous scenarios, local rates of return on capital increase, driven by changes in market capital returns rather than pure profits, making this scenario beneficial for both workers and capital owners.

In the long run, the results are mixed, with overall general improvements. Table 7 summarises longterm sectoral results.

Table 7: Long-run sectoral effects of subsidy and competition reforms following petroleum price declines

\begin{tabular}{|l|c|c|c|c|c|}
\hline \multirow{2}{*}{ Variable } & \multicolumn{4}{|c|}{ Percentage change (departure from baseline) } \\
\cline { 2 - 6 } & $\begin{array}{c}\text { Expatriate } \\
\text { employment }\end{array}$ & $\begin{array}{c}\text { Gross } \\
\text { output }\end{array}$ & $\begin{array}{c}\text { Markup } \\
\text { ratios }\end{array}$ & Scale & Exports/GDP \\
\hline 1 Agriculture & 7.24 & 5.82 & -3.08 & 23.16 & 0.01 \\
\hline 2 Mining & 13.26 & 24.28 & -4.45 & 14.76 & 0.69 \\
\hline 6 Chemical & 31.31 & 34.07 & -1.84 & 5.70 & 0.88 \\
\hline 7 Light manufacturing & 12.60 & 7.64 & -0.19 & -7.68 & 0.06 \\
\hline 8 Heavy manufacturing & 32.69 & 27.76 & -0.63 & -4.99 & 0.48 \\
\hline 9 Electricity & -20.11 & 7.57 & -6.52 & 47.14 & 0.00 \\
\hline 10 Other network services & 7.88 & 9.73 & -2.72 & 7.78 & 0.35 \\
\hline 11 Construction & 12.59 & 14.10 & 0.08 & 2.70 & 0.00 \\
\hline 12 Transport & 68.10 & 77.21 & -3.97 & 14.18 & 4.87 \\
\hline 13 Financial services & 15.41 & 10.93 & -0.84 & -7.84 & 0.04 \\
\hline 14 Other services & 7.72 & 10.97 & -0.55 & 15.86 & 0.34 \\
\hline
\end{tabular}

Source: Simulation results.

Much of the improvement gained over the short run is offset by the larger impairments caused by the decline of the petroleum price on the economy. Real GNP decreases and some non-tradable industries contract as well. Nonetheless, expansion owing to more competitive pricing is particularly relevant in 

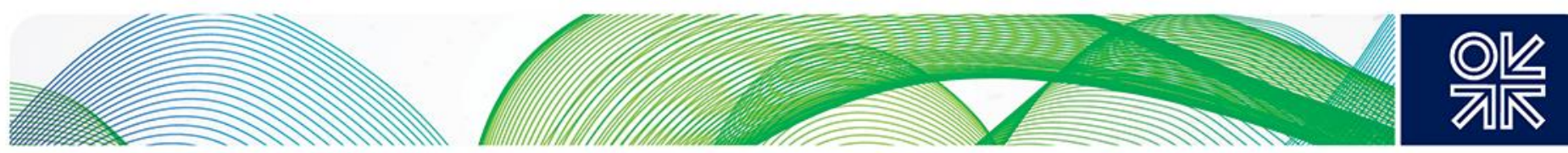

the long run where improvements in efficiency encourage capital stock enlargement, shown as a rebalancing of Kuwait's asset portfolios away from foreign toward domestic productive assets. Yet relative reverse Dutch Disease dynamics coupled with expansions in some non-tradable industries are sufficient to sustain improvements in the real GDP, which is not achieved under the previous scenarios. Non-petroleum exporting industries also export a higher share of their total output, diversifying the government revenue sources. Despite some non-petroleum industrial expansion, the hydrocarbon industry continues to dominate the Kuwaiti economy and governmental revenue sources, causing a large deterioration in the country's fiscal position in the long run. This result confirms that, absent intentional structural change, fiscal unsustainability is a serious concern in a persistently low petroleum price environment. Local petroleum consumption increases in the long run, adding further downward pressures on petroleum export revenue and contributing to a deteriorating government budget. Notwithstanding such declines, welfare payments drop by a small percentage, while household welfare improves overall. With the exception of energy industries and energy-dependent transportation, industries demand additional labour in the long run, which will be mostly filled by expatriate labour. Capital mobility rebalances real rates of return on capital to a level only slightly lower than that of the base scenario. Kuwaiti labour gains in the long run, and capital owners do not endure significant losses. Sustained reductions by $5.25 \%$ in oligopolies' pure profits as a share of GDP drive increased competitiveness of the overall economy.

Importantly, like those of scenarios 2 and 3 above, the results of this simulation highlight the tradeoffs between fiscal sustainability and cost of living stability during periods of high and low oil prices. Figure 4 illustrates the tradeoffs associated with the three reform options examined in the three scenarios.

Figure 4: Comparative tradeoffs and key short-run results of reform scenarios following oil price declines

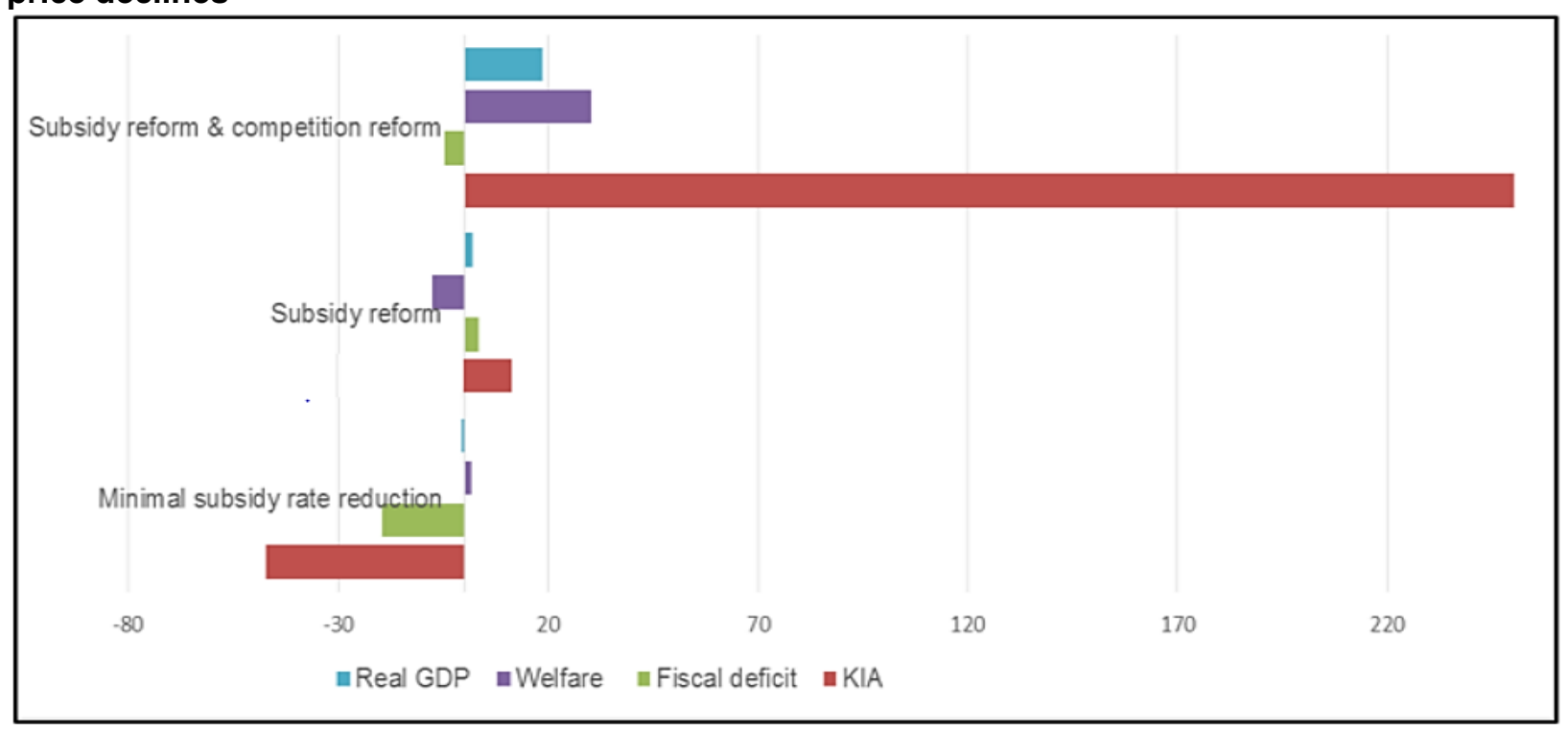

Source: Simulation results.

Note: Axis represents percentage change from baseline.

Comparing these results suggests that subsidy reform alone cannot provide the solution hoped for by the government without the addition of mitigation measures and microeconomic reform, the combination of which offers the most gains. Thus, despite continuous fiscal deficits in the long run and the ensuing potential depletion of KIA funds, the combination of competition reform and energy pricing reform can boost output in a manner that translates to real gains for the various agents in the economy. 

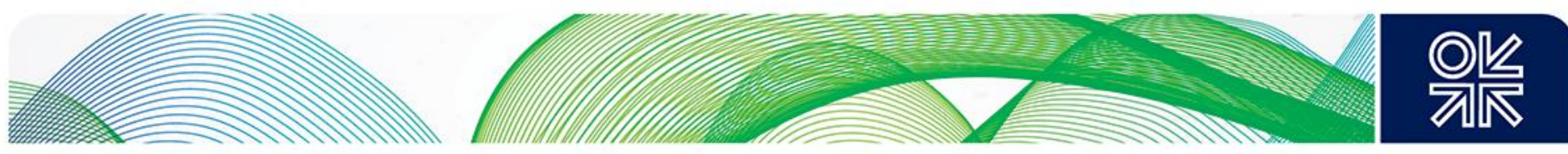

\section{Conclusions}

September 2016's energy pricing reforms were presented and implemented by the Kuwaiti government as the promised solution to fiscal pressures, economic inefficiencies, and excessive local energy consumption. To date, results have been mixed. The reforms remain politically contentious despite a legal verdict by the Appeals Court upholding the government's reforms. The model simulations confirm that the downsides of petroleum price collapse can be successfully managed in Kuwait through the use of its idiosyncratic safety valves: drawing down foreign assets and flexibility in the expatriate labour market. Nonetheless, the availability of these two mechanisms, coupled with petroleum riches, have in the past tended to reduce incentives for efficiency-enhancing structural changes. The government remains the preferred employer and welfare provider, the public sector dominates in most industries and investments in non-petroleum tradable sectors remain weak. Moreover, as the results indicate, these adjustment mechanisms are fiscally unsustainable if the low petroleum price persists. Model simulations actually echo statements by officials of the Central Bank of Kuwait who, in February 2017, reported to a parliamentary committee that existing SWF savings could support anticipated fiscal deficits for only five years before being depleted. The unsustainability of these adjustment mechanisms necessitates fiscal savings and a reexamination of energy pricing reform.

The results also confirm a widely-accepted view that phasing out distortionary energy subsidies can assuage long-run fiscal pressures and yield net welfare benefits. Reforms also reduce rigid government expenditures, thus generating improvements in Kuwait's budgetary and SWF positions. Nevertheless, when applied in combination with petroleum price declines, the simulations demonstrate unanticipated impacts on production, labour-energy linkages, and consumer prices. A particularly important yet under recognised area is the impact on Kuwait's labour market, which changes the economic opportunities available for both firms and workers. As shown in further model simulations and in Figure 4, a tradeoff exists between fiscal stabilisation on the one hand and industrial expansion, welfare gains, and labour market stability on the other, both in the short and long runs. Specifically, the higher levels of energy pricing reform that brought about the intended fiscal stabilisation hampered industrial expansion and welfare gains and caused a higher level of expatriate labour exit. In addition, in the long run, energy pricing reform is unlikely to resolve the government's fiscal challenges. Large cuts to energy consumption subsidies are required to curb local energy demand.

The non-petroleum exporting industries have the potential to expand in "reverse Dutch Disease" effects aided by a depreciating exchange rate, potentially moderating the negative effects of petroleum export declines. Nonetheless, such benefits are optimistic as their realisation depends on these industries' ability to attract labour and capital to higher-valued uses, increase their contribution to GDP, and improve their competitiveness. Based on the existing economic structure and rigidities, this ability remains very weak in the short run and is doubtful in the long term. Kuwaiti industries (including the nationally-owned energy sectors) exhibit distortionary oligopolistic (or monopolistic) behaviour and earn sustained rents that detract from growth-enhancing innovation, hampering economic efficiency, competitiveness, and growth. Final simulations investigating competition reforms show that, with appropriate incentives, the reverse Dutch Disease could be considerably more effective, without becoming a panacea.

In sum, the sets of model simulations highlight the tradeoffs between fiscal sustainability and cost of living stability during periods of high and low petroleum prices. A critical implication of the analyses is that subsidy reform can be part of a larger solution that turns on the tradeoff between local consumption and exports, and between withdrawals from and investments into the SWF. The Kuwaiti economic structure has complexities that limit the potential of pure pricing reform as a universal solution. The distributional and labour market impacts of pricing reform are critically important in an economy where expatriates form $83 \%$ of the labour market and native workers prefer to remain in the public sector. Further, welfare losses juxtaposed against substantial oligopoly rents also entail distributional impacts of implementing pricing reform. Other challenges are posed by the inflexibility of local labour contracts in the public sector coupled with the economic structure and the political economy of rent distribution in 

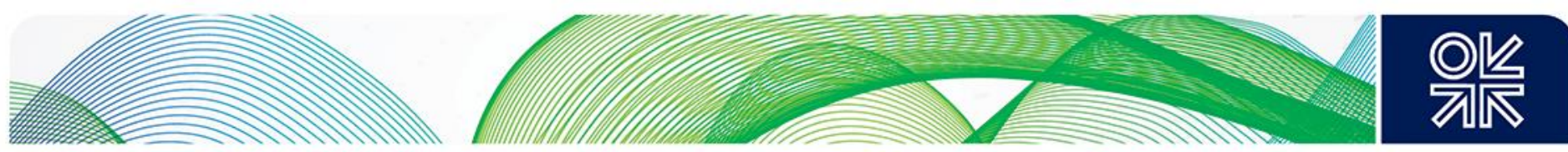

Kuwait. The impacts add social and economic dimensions to subsidy reforms, necessitating extreme care in their implementation.

Therefore, successful implementation of subsidy reform ought to be accompanied by carefully designed mitigation measures and associated microeconomic reforms that address the ensuing sectoral losses and labour effects, and target increased competitiveness in oligopolistic industries, meaningful private sector involvement, and the training and upskilling of workers. Mitigation measures, which can be designed and tested using the economy-wide model presented herein, may also include cash transfers based on income levels rather than on consumption, to help the poorest who are most negatively impacted by subsidy reduction. Policies that manage competition will be very important to achieving sustained benefits and structural changes in the long run. Importantly, these significant gains offer opportunities for economic diversification, increased efficiency, sustained growth, and private sector expansion. The accompanying employment opportunities also offer possible solutions for the bloated public sector and new Kuwaitis entering the labour market. In the electricity sector, in particular, which relies largely on hydrocarbons as input, reform should also accompany investment in energy efficiency and energy supply systems to meet increased demands more efficiently. 

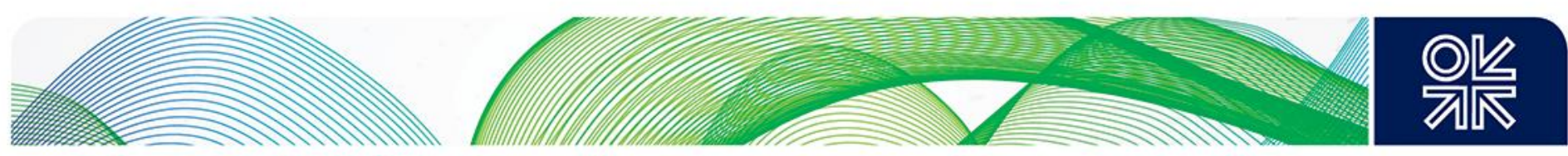

\section{References}

Aghion, P., Akcigit, U., \& Howitt, P. (2013). What do we learn from Schumpeterian growth theory? (No. w18824). Cambridge, MA: National Bureau of Economic Research. Retrieved from http://www.nber.org/papers/w18824.pdf

Aghion, P., \& Howitt, P. (1992). A model of growth through creative destruction. Econometrica, 60(2), 323-351.

AISabah, M. S. S. (1985). General equilibrium analysis of government expenditures in an oil exporting country: The case of Kuwait (Unpublished doctoral dissertation). Harvard University, Cambridge, MA.

Al-Kaisi, E. (1993). Population and labor in Kuwait economy, the problems and the policies. Kuwait Economic Association, Kuwait.

Al-Kuwait Tarfa 'As 'ar al- Kahraba' wal Ma' 'ala al-Muqimin. (2016, April 14). Agence France Presse, France24 Arabic. [Kuwait Raises Electricity and Water Prices for Expatriates]. Retrieved from http://www.france24.com/en/20160414-الكويت-الماء-الكهرباء-رفع-الأسعار -المقيمون-تمييز

Al-Sennari, R. (2016, January 4). Al-Kuwait tadkhul zaman aḍdara'ib. Al-Ra'i. [Kuwait enters the era of taxes, Al-Ra'i ]. Kuwait City, Kuwait. Retrieved from http://www.alraimedia.com/ar/article/ economics/2016/01/04/647157/nr/kuwait

Arze Del Grado, F., Coady, D., \& Gillingham, R. (2012). The unequal benefits of fuel subsidies: A review of evidence for developing countries. World Development, 40(11), 2234-2248. https://doi.org/10.1016/j.worlddev.2012.05.005

Asano, A., \& Tyers, R. (2015). Third arrow reforms and Japan's economic performance. (UWA Discussion Paper Series DP 15.17). Perth, WA, Australia: University of Western Australia. Retrieved from http://www.business.uwa.edu.au/_data/assets/pdf_file/ 0012/2765847/15.17-Asano,-A.-and-Tyers,-R.-Third-Arrow-Reforms-and-Japans-EconomicPerformance.pdf

Balistreri, E. J., \& Markusen, J. R. (2009). Sub-national differentiation and the role of the firm in optimal international pricing. Economic Modelling, 26(1), 47-62.

Blanchard, O., \& Giavazzi, F. (2003). Macroeconomic effects of regulation and deregulation in goods and labor markets. The Quarterly Journal of Economics, 118(3), 879-907. https://doi.org/10.1162/00335530360698450

Burney, N. A., \& Al-Mutairi, N. (1993). Household consumption patterns in Kuwait. The Middle Eastern Business and Economic Review, 5(2), 1-12.

BuShehri, M. A. M., \& Wohlgenant, M. K. (2012). Measuring the welfare effects of reducing a subsidy on a commodity using micro-models: An application to Kuwait's residential demand for electricity. Energy Economics, 34(2), 419-425. https://doi.org/10.1016/j.eneco.2011.08.001

Corden, W.M. (2012). The Dutch Disease in Australia: Policy options for a three-speed economy. (ANU Arndt-Corden Department of Economics, Working Paper 10). Canberra, ACT: The Australian National University.

Dixon, P., Parmenter, B., Sutton J., \& Vincent D. (1982). ORANI: A Multisectoral Model of the Australian Economy, Contributions to Economic Analysis. New York: North-Holland Publishing Company.

Energy Information Administration. (2016). World Energy Outlook. Washington, DC: Author.

Farouq, M., \& Mousa, A. (2017, May 8). 225 miliun dinar.. ḥasilat rusum taḥwilat al-wafidin. Al-'Anba' [225 million dinar.. total fees on expatriates' remittances, Al-Anba]. Kuwait City, Kuwait. مليون-دينار---مetrieved from http://www.alanba.com.kw/ar/economy-news/743686/08-05-2017 حصيلة-رسوم-تحويلات-الو افدين 

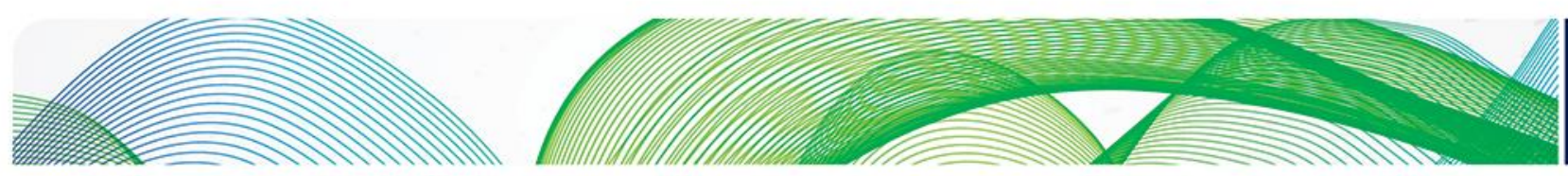

Gahvari, F. \& Taheripour, F. (2011). Fiscal reforms in general equilibrium: Theory and an application to the subsidy debate in Iran. Journal of Economic Analysis and Policy, 11(1), 1-54.

Gelan, A. (2014). Quantifying economy-wide impacts of reducing subsidy to the electricity sector in Kuwait. Paper submitted to the Economic Modeling Conference, Indonesia. Retrieved from https://ideas.repec.org/p/ekd/006356/7106.html

Grossman, G. M., \& Helpman, E. (2014). Growth, trade, and inequality. Cambridge, MA: National Bureau of Economic Research. Retrieved from http://www.nber.org/papers/w20502

Gunasekera, H. D., \& Tyers, R. (1990). Imperfect competition and returns to scale in a Newly Industrialising Economy: A General Equilibrium Analysis of Korean Trade Policy. Journal of Development Economics, 34, 223-247.

Harris, R. (1984). Applied general equilibrium analysis of small open economies with scale economies and imperfect competition. American Economic Review, 74(5), 1016.

Hartley, P., \& Medlock III, K. B. (2008). A model of the operation and development of a National Oil Company. Energy Economics, 30(5), 2459-2485. https://doi.org/10.1016/j.eneco.2007.12.017

Hartley, P., \& Trengove, C. (1986). Who Benefits from Public Utilities? Economic Record, 62(2), 163179. https://doi.org/10.1111/j.1475-4932.1986.tb00892.x

Horridge, M. (1987). The long term costs of protection: experimental analysis with different closures of and Australian computable general equilibrium model (doctoral dissertation). The University of Melbourne, Melbourne, Australia.

Khorshid, M. (1990). A dynamic macroeconomic model for Kuwait: Analysis of the medium-term path. Energy Economics, 12(4), 289-301. https://doi.org/10.1016/0140-9883(90)90019-C

Khorshid, M. (1991). A Social-accounting-matrix-based Long-term Model for a Gulf Cooperation Council Country: the Kuwaiti Case. Economic Systems Research, 3(3), 299-314. https://doi.org/10.1080/09535319100000023

Kuwait Central Statistical Bureau. (2013). Annual general statistics. Kuwait City: Author.

Kuwaiti Stock Exchange (2012). Dalil al-mustathmir [Industry reports- the Investor's guide]. Kuwait City: Author.

Lin, B., \& Li, A. (2012). Impacts of removing fossil fuel subsidies on China: How large and how to mitigate? Energy, 44(1), 741-749. https://doi.org/10.1016/j.energy.2012.05.018

Menezes, F. M. (2009). Consistent regulation of infrastructure businesses: Some economic issues. Economic Papers: A Journal of Applied Economics and Policy, 28(1), 2-10.

Mu'akkida Sịhat 'ljra' at al-Hukuma al-Ttanfithiya, Al-Kuwait: Maḥkamat al-Isti' naf Taqdi Bisịat Qarar al-Hukuma Raf' 'As'ar al-Banzin. (2017, April 24). Al-Wi' am. [Confirming the Executive Branch's Actions, Kuwait: The Court of Appeals Determines the Correctness of the Government's Decision to Raise Gasoline Prices, Al-Wi am]. Kuwait City, Kuwait. Retrieved from http://www.alweeam.com.sa/461689/الكويث_محكمة_الاستئناف_تقضي_بصحة_ تقرار

Ocampo, J. A., Rada, C., \& Taylor, L. (2009). Growth and policy in developing countries: a structuralist approach. New York: Columbia University Press.

Plante, M. (2014). The long-run macroeconomic impacts of fuel subsidies. Journal of Development Economics, 107, 129-143.

Public Authority for Civil Information. (2015). Altaqarir al-'ihșa'iyya [The statistical reports]. Kuwait City, Kuwait.

Schumpeter, J. A. (1911). The Theory of economic development: An inquiry into profits, capital, credit, interest and the business cycle. Second publication. Cambridge, MA: Harvard University Press.

Schumpeter, J. A. (1942). Capitalism, socialism and democracy. London, UK: Routledge printed 1976.

Segerstrom, P. S., Anant, T. C., \& Dinopoulos, E. (1990). A Schumpeterian model of the product life cycle. The American Economic Review, 1077-1091. 

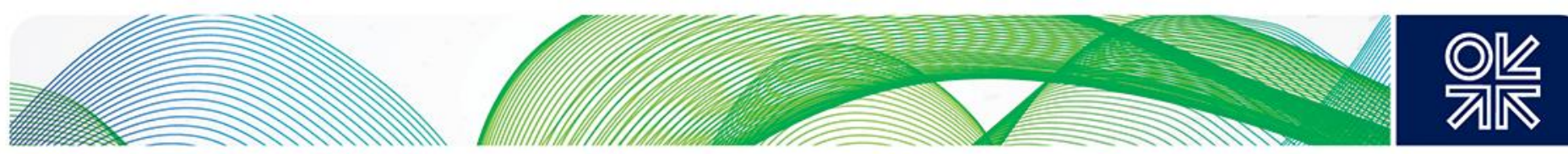

Shehabi, M. (2017). The hidden face of subsidies reforms following oil price declines in Kuwait: An economy-wide analysis. Challenges Facing GCC Oil \& Gas Exports, Naji Abi Aad ed., Gulf Research Center Cambridge. UK: Gulf Research Center Cambridge. Forthcoming.

State of Kuwait Ministry of Finance (2006). Qanun raqam 46 li sanat 2006 fi sha'n azzakat wa musahamat asharikat al-musahima al- amma wa al-muqfala fi mizaniyat addawla [Law number 46 for year 2006 regarding Zakat and contribution of public and closed shareholding companies in the State's budget]. Kuwait City: Author. Retrieved from http://www.mof.gov.kw/Desicions/Decree/PDF/Q46-2006.pdf

State of Kuwait (2010). Qanun raqam 37 li sanat 2010 fi sha'n tanthim baramij wa 'amaliyat attakhșiș [Law number 27 for year 2010 regarding the organization of privatization plans and processes]. Kuwait Direct Investment Promotion Authority. Kuwait City: Author. Retrieved from https://e.kdipa.gov.kw/main/372010.pdf

Tyers, R. (2005). Trade reform and manufacturing pricing behavior in four archetype Asia-Pacific economies. Asian Economic Journal, 19(2), 181-203. https://doi.org/10.1111/j.14678381.2005.00209.x

Tyers, R. (2014). Asymmetry in boom-bust shocks: Australian performance with oligopoly (Centre for Applied Macroeconomic Analysis (CAMA), Crawford School of Public Policy, CAMA Working Paper No. 2014-50). Canberra, ACT: The Australian National University. Retrieved from https://ideas.repec.org/p/een/camaaa/2014-50.html

World Bank (2017). Energy Use, DataBank. Washington DC: Author. 

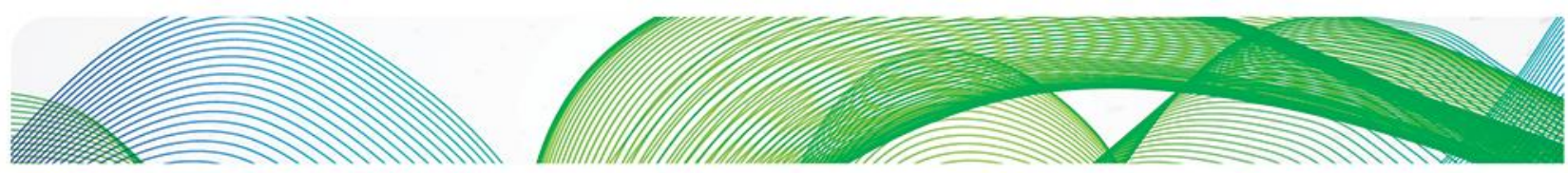

\section{Appendix A:}

\section{The SAM and its Representation of Broad Economic Structure}

The SAM is an extension of input-output models that display transactions as a circular flow of the government's incomes and expenditures. It combines detailed data characterising economic linkages between regions using country-specific data to enable the quantification of inter-sectoral flows within and between regions.

The constructed SAM for Kuwait for 2013 drew from the following data sources for 2013 (the most recently available), obtained from the Kuwaiti government:

- Input and Output Table 2013, obtained from CSB;

- Supply and Use Table 2013, obtained from CSB;

- Production Matrix 2013, obtained from CSB:

- Kuwait's national accounts, obtained from Kuwait's Ministry of Planning;

- Kuwait's balance of payments, obtained from the Central Bank of Kuwait;

- Kuwait's oil production and information, publically available from KPC;

- Listed companies' sectoral market capitalisation and revenue, obtained from the Kuwaiti Stock Exchange website;

- Sectoral revenue, costs, number of employees, and ownership structure, obtained from the CSB; and

- Kuwaiti labour market data, obtained from CSB and the Public Authority for Civil Information (PACI).

The database construction reflects key features of Kuwait's economy.

\section{Government}

Due to data limitations, the SAM database cannot address the public-private contrast directly; rather, it offers some representation of this contrast in the analysis.

\section{Labour representation}

An ideal representation would disaggregate labour by the private and public sectors and by nationality; however, such disaggregation could not be reliably constructed due to data limitations. The adopted disaggregation of labour in the model allows the examination of the impact of export price shocks and policy interventions on employment, wages, and the temporary worker population. The disaggregation of labour-related data between unskilled and skilled labour has been done with consideration to the International Labour Organization (ILO) classification of occupations and corroboration with sectorspecific data from PACl. 

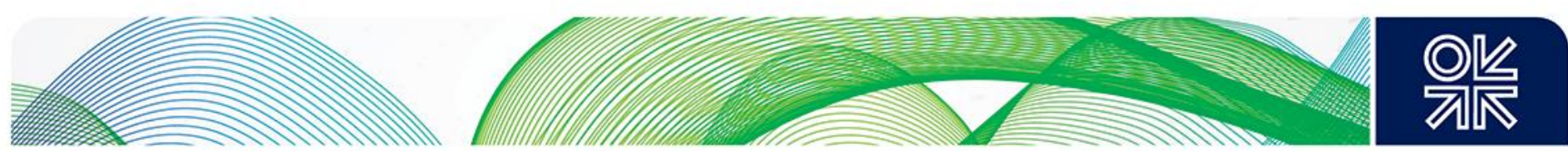

\section{Appendix B:}

\section{Key Modelling Specifications}

This appendix complements the description of the model offered in the main text of the paper. It emphasises the model's representation of demand elasticities of the various demand sources and products' prices and details the tax system built into it.

\section{B.1. Oligopoly Markups}

Oligopolistic firms operate in differentiated product markets. As such, each firm exploits its monopoly over the supply of its own product variety through selecting its price, and therefore its markup, so that it maximises its profit. Within a given industry (economic sector), each firm faces an elasticity of demand that depends on the individual elasticities of the various demand sources as well as on the number of other firms and the degree of pricing collusion between them. Symmetry within each economic sector implies a common optimal unregulated markup for each firm.

\section{B.2. Demand Elasticities}

The elasticity of demand $\left(\varepsilon_{i}\right)$ facing firms in a given industry $i$ is a downward-sloping demand curve that depends on the weighted average of the elasticities of demand in the above-mentioned five markets. Calculating this average depends on the initial shares $S_{i}^{j}$ of the demand facing each industry. Table B. 1 calculates the shares drawing upon the SAM data.

Table B.1. Demand shares per industry 2013

\begin{tabular}{|l|c|c|c|c|c|}
\hline $\begin{array}{l}\text { Industry/ } \\
\text { Percentage }\end{array}$ & Final & Government & Investment & Intermediate & Export \\
\hline 1 Agriculture & 87.1 & 3.2 & 0.0 & 0.2 & 9.5 \\
\hline 2 Mining & 8.5 & 56.2 & 0.0 & 1.0 & 34.2 \\
\hline 3 Crude oil & 1.7 & 49.3 & 0.0 & 0.9 & 48.2 \\
\hline $\begin{array}{l}\text { 4 Gas and petro- } \\
\text { services }\end{array}$ & 7.6 & 0.0 & 0.0 & 0.7 & 91.8 \\
\hline 5 Oil refining & 8.1 & 71.7 & 0.0 & 3.6 & 16.7 \\
\hline 6 Chemical & 8.3 & 55.8 & 0.0 & 15.8 & 20.1 \\
\hline 7 Light manufacturing & 48.4 & 9.5 & 0.0 & 4.0 & 38.1 \\
\hline $\begin{array}{l}\text { 8 Heavy } \\
\text { manufacturing }\end{array}$ & 12.6 & 35.6 & 0.0 & 27.9 & 23.9 \\
\hline 9 Electricity & 96.5 & 0.0 & 0.0 & 0.0 & 3.5 \\
\hline $\begin{array}{l}\text { 10 Other network } \\
\text { services }\end{array}$ & 41.9 & 33.8 & 0.0 & 0.0 & 24.4 \\
\hline 11 Construction & 0.0 & 0.0 & 0.0 & 96.1 & 3.9 \\
\hline 12 Transport & 44.0 & 36.3 & 0.0 & 0.0 & 19.7 \\
\hline 13 Financial services & 19.6 & 4.3 & 0.0 & 0.0 & 76.2 \\
\hline 14 Other services & 45.5 & 2.3 & 47.4 & 0.9 & 3.9 \\
\hline
\end{tabular}

Source: Author's CGE model database (SAM) constructed for 2013.

In addition, the elasticity depends on component elasticities of substitution, firm numbers (which are assumed exogenous in this paper's analysis), and the conjectural variation parameters in industry $i\left(\mu_{i}\right)$. The conjectural variation relationship allows firms to collude on price, so the overall oligopoly pricing choice is determined influence of pricing choices by any individual firm $k$, on the price set by of firm $j$.

The demand elasticities depend on the structure of the model. They are essential to the capture of oligopoly behaviour since they determine the size of markup ratios via an exchange rate equation in the 

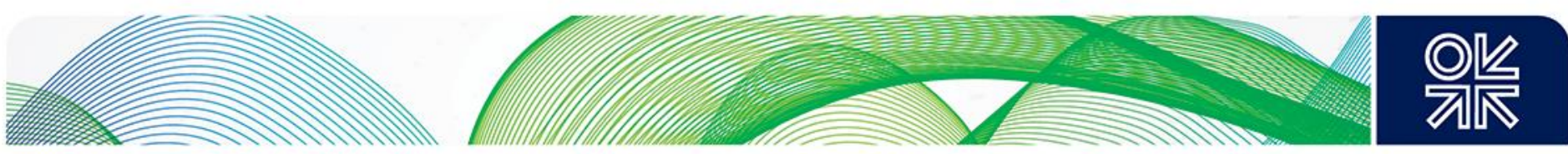

model (which follows a standard definition of the common currency ratio of the home and foreign GDP price levels) and investment expenditure impacted by local and foreign interest rates. These relationships are complex and Tyers (2014) details their analytics.

For example, the final demand elasticity is expressed as follows:

$\varepsilon_{i}^{F}=-\eta_{i}^{F}+\frac{1}{n_{i}}\left\{\left(\sigma_{i}^{F}-1\right) \delta_{i}^{F}\left(\frac{\widehat{P}_{i H}}{\widehat{P}_{i}^{F}}\right)^{\left(1-\sigma_{i}^{F}\right)}+\left(\eta_{i}^{F}-\sigma_{i}^{F}\right)\left(1+\left(n_{i}-1\right) \mu_{i}\right)\right\}$,

where $\eta_{i}^{F}$ is the elasticity of substitution of final demand across home varieties in sector $i, \delta_{i}^{F}$ is the home share in final demand for product $i, \sigma_{i}^{F}$ is the elasticity of substitution of final demand for good $i$ between domestic and foreign countries, $n_{i}$ is the number of domestic firms in industry $i, \hat{P}_{i H}$ is the CES composite price of all home varieties of product $i$, and $\hat{P}_{i}^{F}$ is the CES composite of home and foreign final product prices in the domestic market, weighted by domestic consumption shares. The behaviour of government consumption and the expenditure of the capital goods sector on home and foreign products are similar, except that the government pays no import duties or consumption tax and the capital goods sector pays no import duties. Table B.2 lists initial demand elasticities per sector, calculated using the model equations.

Table B.2: Initial demand elasticities and markups per sector

\begin{tabular}{|l|c|c|c|c|c|c|}
\hline Industry & Final & Government & Investment & Intermediate & Exports & $\begin{array}{c}\text { Weighted } \\
\text { average } \\
\text { elasticity }\end{array}$ \\
\hline 1 Agriculture & -1.8 & -4.7 & -3.0 & -3.0 & -8.5 & -2.2 \\
\hline 2 Mining & -1.0 & -3.6 & -1.0 & -3.0 & -4.0 & -3.4 \\
\hline 3 Crude oil & -1.0 & -3.5 & -1.0 & -12.0 & -14.1 & -12.8 \\
\hline $\begin{array}{l}\text { 4 Gas and petro- } \\
\text { services }\end{array}$ & -3.6 & -4.8 & -2.1 & -30.0 & -15.0 & -25.6 \\
\hline 5 Oil refining & -7.8 & -5.7 & -4.7 & -20.0 & -12.2 & -12.9 \\
\hline 6 Chemical & -7.1 & -5.4 & -2.9 & -8.0 & -7.8 & -7.0 \\
\hline 7 Light manufacturing & -5.3 & -12.0 & -6.0 & -12.0 & -16.6 & -8.9 \\
\hline $\begin{array}{l}\text { 8 Heavy } \\
\text { manufacturing }\end{array}$ & -5.5 & -5.4 & -3.5 & -12.0 & -15.0 & -9.9 \\
\hline 9 Electricity & -3.8 & -3.6 & -1.8 & -33.0 & -4.7 & -4.6 \\
\hline $\begin{array}{l}\text { 10 Other network } \\
\text { services }\end{array}$ & -1.0 & -2.5 & -1.5 & -5.0 & -3.8 & -2.9 \\
\hline 11 Construction & -5.1 & -5.1 & -4.9 & -20.0 & -6.2 & -5.5 \\
\hline 12 Transport & -4.2 & -5.6 & -2.9 & -3.0 & -8.3 & -5.5 \\
\hline 13 Financial services & -6.5 & -7.0 & -3.5 & -5.0 & -8.6 & -5.4 \\
\hline 14 Other services & -5.4 & -4.8 & -2.0 & -5.0 & -12.7 & -5.2 \\
\hline
\end{tabular}

Source: Author's CGE model calculations.

\section{B.3. Domestic Prices of Imported Goods}

The formulation of these is as follows:

$p_{i}^{*}=\frac{p_{i}^{w}\left(1+\tau_{i}^{M}\right)\left(1+\tau_{i}^{C}\right)}{e}$,

Where $p_{i}^{w}$ is the exogenous foreign currency price of goods imported by Kuwait and produced in the rest of the world; $\tau_{i}^{M}$ is the ad valorem tariff rate; $\tau_{i}^{C}$ is the consumption tax rate on final demand for the products of industry $i$; and $e$ is the exchange rate. 

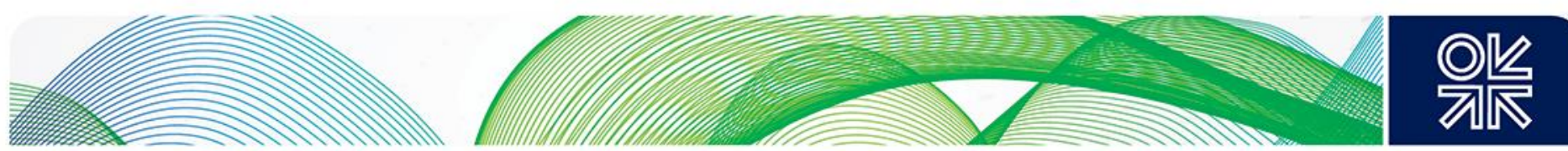

\section{B.4. Domestic Prices of Home Products}

These are marked up over average variable cost. The production function is Cobb-Douglas in variable factors and inputs, with output elasticities $\alpha_{i}$ for capital, $B_{k i}$ for factors $k$ and $\gamma_{j i}$ for inputs $j$ and that the subaggregation of imported and domestic inputs is CES. The unit variable costs in (5) are calculated with reference to $\hat{P}_{j i}^{I}$, is a CES composite of home and imported input prices weighted by the domestic and imported shares specific to consuming industry $i$. It is expressed as:

$\hat{P}_{j i}^{I}=\left[\phi_{j i}\left(p_{j}\right)^{\left(1-\sigma_{j}^{I}\right)}+\left(1-\phi_{j i}\right)\left(p_{j}^{*}\right)^{\left(1-\sigma_{j}^{I}\right)}\right]^{\frac{1}{\left(1-\sigma_{j}^{I}\right)}}$,

where $\phi_{j i}$ is the domestic share of inputs from industry $j$ used by industry $i$. This relationship implies that domestic producer prices are simply higher by the markup, $m_{i}: p_{i}=m_{i} v_{i}, \quad \forall i$.

\section{B.5. Prices of Home Product Exports in Foreign Markets}

These prices are in foreign currency, so they depend on the home producer price, the exchange rate, the export subsidy rate $S_{i}^{X}$ and the foreign import tariff rate, $\tau_{i}^{* M}$, expressed as:

$p_{i}^{e}=\frac{p_{i} e\left(1+\tau_{i}^{* M}\right)}{\left(1+S_{i}^{X}\right)}, \quad \forall i$

\section{B.6. Taxes and Subsidies}

In the model specifications, the government raises tax revenue from both direct and indirect taxation, the rates applied to each being exogenous and constant but the revenues earned depend on levels of economic activity. Total tax revenue is then the sum of the individual components, which can be raised from each source as expressed below. Subsidies and governmental transfers will be represented in the same way as taxes specifying the rates as a negative tax.

Direct income tax revenue

$T_{Y}=\sum_{i=1}^{N} \tau_{K_{i}}\left(r K_{i}+\pi_{i}\right)+\tau_{U_{K}} w_{U_{K}} L_{U_{K}}+\tau_{S_{K}} w_{S_{K}} L_{S_{K}}+\tau_{U_{N}} w_{U_{N}} L_{U_{N}}+\tau_{S_{N}} w_{S_{N}} L_{S_{N}}$,

where $r$ is the home real financing rate (bond yield); $K_{i}$ denotes total capital stock in industry $i$; $\pi_{i}$ denotes total pure profit in industry $i$; and the subscripts " $U$ " and " $S$ " denote unskilled and skilled labour (production workers and the combination of professionals and para-professionals as per the ILO classification of occupations). The sub-subscripts "K" and "N" denote Kuwaiti and non-Kuwaiti labour. $\tau$ is the income tax rate applied on income earned by the respective different group of labour. To represent subsidies, government transfers and wage assistance, the model would specify $\tau<0$.

Income tax/subsidy rates, to the extent they are applied, are approximated by flat rates deduced as the quotient of revenue and the tax base. Including tax rates even when tax rates are almost negligible enables the capture and assessment of various tax policies.

Import tariff revenue

$T_{M}=\sum_{i=1}^{N} \tau_{i}^{M}\left(M_{i+} I_{i}^{*}\right) \frac{p_{i}^{w}}{e}$

where $I_{i}^{*}$ is foreign investments in industry $i$.

\section{Export tax revenue}

$T_{X}=\sum_{i=1}^{N}\left(-s_{i}^{X}\right) p_{i} X_{i}$

where $s_{i}^{X}$ denotes the net power of the export subsidy rate in industry $i$. 

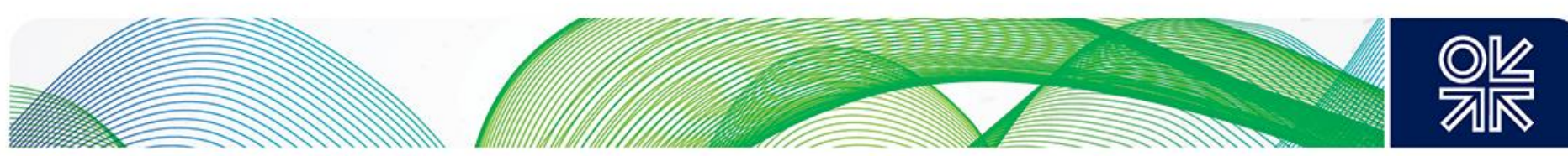

\section{B.7. GNP and GDP}

The model calculates national income, GNP, as the sum of payments made to domestically-owned factors of production. It also accounts for the home share of any net profits (or losses) made; net income from indirect taxation; revenue from direct (income) taxation $T_{Y}$; and net inflows from abroad denoted as $B$. The formulation is, thus, as follows.

$$
Y=r K_{D}+\sum_{k=1}^{K} w_{k} L_{k}+\left(\frac{K_{D}}{K_{T}}\right) \sum_{i=1}^{N} \pi_{i}+\left(T-T_{Y}\right)+\frac{B}{e}+\left(1-\frac{K_{D}}{K_{T}}\right) \tau_{K}^{*}\left(r\left(K_{T}-K_{D}\right)+\sum_{i=1}^{N} \pi_{i}\right) .
$$

In effect, $B$ is the net income component of the current account and unrequited transfers.

GDP measures only income from production in the domestic economy. Therefore, in the model its calculation excludes factor payments as well as other flows to and from abroad, as follows:

$$
G D P=r K_{T}+\sum_{k=1}^{K} w_{k} L_{k}+\sum_{i=1}^{N} \pi_{i}+\left(T-T_{Y}\right) \text {. }
$$

\section{B.8. Real Exchange Rate}

The model allows measuring different economic variables in real terms. The real exchange rate measured the home and foreign GDP price levels expressed in a common currency. The model, thus, calculates the real exchange rate as the ratio of the home price $\left(P_{Y}\right)$ of a bundle of (traded and nontraded) goods and services at home relative to that abroad $\left(P^{*} y\right)$, as follows,

$e_{R}=\frac{P_{Y}}{\left(\frac{P_{Y}^{*}}{E}\right)}=E \frac{P_{Y}}{P_{Y}^{*}}$,

where $e_{R}$ is the real exchange rate and $E$ is the nominal exchange rate, both expressed according to the financial convention. 